University of Nebraska - Lincoln

DigitalCommons@University of Nebraska - Lincoln

$4-24-2010$

\title{
Immunoaffinity chromatography: an introduction to applications and recent developments
}

Annette C Moser

University of Nebraska - Lincoln, moserac@unk.edu

David S. Hage

University of Nebraska-Lincoln, dhage1@unl.edu

Follow this and additional works at: https://digitalcommons.unl.edu/chemistryhage

Moser, Annette C and Hage, David S., "Immunoaffinity chromatography: an introduction to applications and recent developments" (2010). David Hage Publications. 25.

https://digitalcommons.unl.edu/chemistryhage/25

This Article is brought to you for free and open access by the Published Research - Department of Chemistry at DigitalCommons@University of Nebraska - Lincoln. It has been accepted for inclusion in David Hage Publications by an authorized administrator of DigitalCommons@University of Nebraska - Lincoln. 


\title{
Immunoaffinity chromatography: an introduction to applications and recent developments
}

\author{
Annette C Moser ${ }^{1}$ and David S Hage ${ }^{2}$ \\ ${ }^{1}$ Chemistry Department, University of Nebraska at Kearney, Kearney, NE 68849-1150, USA, Tel.: \\ +1 308865 8802, Fax: +1 308865 8399, moserac@unk.edu \\ ${ }^{2}$ Chemistry Department, University of Nebraska-Lincoln, Lincoln, NE 68588-0304, USA, Tel.: +1 \\ 402472 2044, Fax: +1 402472 9402, dhage@unlserve.unl.edu
}

\section{Abstract}

Immunoaffinity chromatography (IAC) combines the use of LC with the specific binding of antibodies or related agents. The resulting method can be used in assays for a particular target or for purification and concentration of analytes prior to further examination by another technique. This review discusses the history and principles of IAC and the various formats that can be used with this method. An overview is given of the general properties of antibodies and of antibodyproduction methods. The supports and immobilization methods used with antibodies in IAC and the selection of application and elution conditions for IAC are also discussed. Several applications of IAC are considered, including its use in purification, immunodepletion, direct sample analysis, chromatographic immunoassays and combined analysis methods. Recent developments include the use of IAC with CE or MS, ultrafast immunoextraction methods and the use of immunoaffinity columns in microanalytical systems.

Immunoaffinity chromatography (IAC) is a type of LC in which the stationary phase consists of an antibody or antibody-related reagent. This technique represents a special sub category of affinity chromatography, in which a biologically related binding agent is used for the selective purification or analysis of a target compound. The selective and strong binding of antibodies for their given targets has made these agents of great interest for many years as immobilized ligands in affinity chromatography [1-4]. Other methods sometimes included under the heading of IAC are those that use immobilized targets for antibody purification. However, in this review, the emphasis will be placed on methods that use antibodies as the immobilized ligands.

The earliest use of IAC and related methods was in the selective purification of compounds from biological samples. For instance, target compounds immobilized onto kaolin and charcoal were used as early as 1935 to isolate antibodies associated with syphilis and TB [5]. A total of 1 year later, Karl Landsteiner and co-workers isolated antibodies by using

\section{(C) 2010 Future Science Ltd}

Correspondence to: David S Hage.

Financial \& competing interests disclosure

The authors have no relevant affiliations or financial involvement with any organization or entity with a financial interest in or financial conflict with the subject matter or materials discussed in this manuscript. This includes employment, consultancies, honoraria, stock ownership or options, expert testimony, or royalties. Part of the work described in this review was supported by the NIH under grants R01 GM044931 and R01 DK069629. Some of the work described in the areas of the chromatographic immunoassays and ultrafast immunoextraction are the subjects of US Patents $6,720,193$ and $6,727,104$.

No writing assistance was utilized in the production of this manuscript. 
targets immobilized onto chicken erthyrocyte stroma by a diazo coupling method [6]. The first modern use of IAC is generally attributed to Campbell et al., who immobilized serum albumin to $p$-aminobenzylcellulose in 1951 for use in antibody purification [7]. Since that time, there have been thousands of reports using IAC for both the isolation of chemicals or biochemicals $[1,3,4,8-12]$ and analytical applications [2,4,8,11-20].

This review will first examine the main components and underlying principles of IAC. This will include an overview of the general properties of antibodies and of antibody-production methods. The supports and immobilization methods used with antibodies in IAC and the selection of application and elution conditions for IAC will also be discussed. Several applications of IAC will then be considered, including the use of this method in purification, immunodepletion, direct sample analysis and chromatographic immunoassays. The use of IAC in combination with other methods for compound analysis will also be examined. Recent developments in this field will then be presented, including the combined use of IAC with CE or MS, the creation of ultrafast immunoextraction methods and the use of immunoaffinity columns in micro-analytical systems. A variety of applications will be listed in this review but an emphasis will be given to those that are related to bioanalysis.

\section{Basic components of IAC}

\section{Structure \& properties of antibodies}

The basis for IAC relies on the selective binding of antibodies. This binding is a result of a large variety of noncovalent interactions that can occur between an antibody and an antigen and can result in association equilibrium constants in the range of $10^{5}-10^{12} \mathrm{M}^{-1}$ [20]. It has been estimated that the human body is able to produce between $10^{7}$ and $10^{8}$ different types of antibodies, with each capable of binding to a separate antigen [1]. The typical structure of an antibody, using IgG as an example, consists of four polypeptide chains. These four chains consist of two identical heavy chains and two identical light chains that are linked by disulfide bonds to from a Y-shaped structure (FIGURE 1). The lower stem region of an antibody is referred to as the $F_{c}$ region and is highly conserved from one antibody class to the next. The upper arms of the antibody are called the $F_{a b}$ regions. The amino acid sequences in the $F_{a b}$ regions are identical within a single type of antibody but are highly variable between different antibodies. It is this variability that allows antibodies to bind a wide range of antigens.

A foreign agent that is capable of initiating antibody production is called an antigen. Common antigens include viruses, bacteria and foreign proteins from animals and plants that are capable of producing an immune response [1]. Due to the large size of naturally occurring antigens, antibodies that bind to several different regions of the antigen with a range of binding affinities are often generated. Each individual location on an antigen that can bind to a given antibody is called an epitope. In order for a substance to be recognized by the body's immune system and to lead to the production of antibodies, this substance must have a size that corresponds to a mass of several thousand Daltons [1]. Antibodies can also be produced against smaller substances, but these substances first must be coupled to a larger species (e.g., a carrier protein) before antibody production can occur. A small substance that is used to produce antibodies after being linked to a carrier agent is known as a hapten.

The two main types of antibodies that are used in IAC are polyclonal antibodies and monoclonal antibodies. Polyclonal antibodies are produced from multiple cell lines within the body and as a population can bind a variety of epitopes on a single antigen with a range of binding strengths. Monoclonal antibodies are produced by the fusion of a myeloma cell line with spleen cells obtained from an animal that has been immunized with the desired 
antigen. Because monoclonal antibodies are generated from a single cell line, they bind to a single epitope with identical binding affinities. Two other types of antibodies that can be used in IAC are autoantibodies, which are polyclonal antibodies obtained from patients with auto immune diseases, and anti-idiotypic antibodies, which are antibodies that can mimic the interactions of antigens, hormones or substrates for cell receptors [1].

Recent advances have led to the production of artificial antibodies that have high binding affinities [21]. These artificial antibodies can be produced by combining two or more ligands with moderate affinity on a synthetic tether or polymer. One method of producing these so-called synbodies utilizes a small library of short, unstructured polypeptides that are capable of binding independent sites on a protein target. These polypeptides can easily be linked to bivalent reagents at different distances and orientations [21]. More information on antibody libraries, synbodies and the related topic of recombinant antibodies can be found elsewhere [22-24].

\section{Production of antibodies}

Polyclonal antibodies can be produced against a given target by injecting the antigen or a hapten-carrier conjugate into a laboratory animal (e.g., a mouse, rabbit, goat or sheep) [1]. Often this solution of the antigen or hapten-carrier conjugate contains an enhancing agent called an adjuvant. After this initial injection, blood samples from the animal are collected after approximately a month (e.g., 3-4 weeks, although the exact times used in this sequence may vary) and tested for the presence of antibodies that are specific for the desired target. Another injection of the antigen or hapten conjugate (called a 'booster') is then made into the animal. The animal's blood is then retested later (e.g., after 10 days) for the presence of antibodies. Based on the antibody levels that are detected, the animal can be allowed to rest for a period of time (e.g., a few weeks) before being administered another booster injection. This booster/bleed routine can be repeated several times until the antibody concentrations for the required antigen reach the desired level (i.e., as determined by an assay of the blood). At this point, antibody-containing serum can be collected from the animal and stored for later use (FIGURE 2) [1].

The antibodies that are produced upon the first exposure of an animal to a foreign agent are typically IgM class antibodies. After repeated exposure, IgG class antibodies will also be produced. It is this secondary immune response that produces antibodies that are best suited for IAC applications. Antibodies that are produced through the normal immune response are polyclonal antibodies that can bind with various strengths and to a variety of epitopes on the antigen. Before these antibodies can be used in IAC, some further purification is often required. This purification may involve the use of ion-exchange chromatography [25], precipitation with ammonium or dextran sulfate [26] or isolation on a protein A or protein $\mathrm{G}$ column [27]. The isolated products from each of these techniques will contain some antibodies that do not bind to the desired antigen, but these other antibodies can later be removed by using an immobilized antigen column [28].

Monoclonal antibodies can be produced by isolating a single antibody-producing cell and combining this cell with a carcinoma or myeloma cell (FIGURE 3). The resulting hybrid cell line, called a hybridoma, is relatively easy to culture and grow for long-term antibody production [1]. This approach for monoclonal antibody production was first reported by Köhler and Milstein in 1975 [29]. In this method, a solution of the antigen or the haptencarrier conjugate is mixed with adjuvant and injected subcutaneously into an animal. The animal is later given a booster shot, killed and the spleen harvested. The lymphocyte cells are mixed with myeloma cells in the presence of polyethylene glycol, which is added to promote cell fusion. The cells are then grown in the presence of drugs that kill myeloma cells and unfused lymphocytes, but permit the growth of hybridoma cells. Individual 
cultures of hybridomas are examined for the production of specific antibodies and those that make the desired antibody are cloned to produce a homogenous culture of cells making a monoclonal antibody. Although this process can be tedious and difficult, it has the advantage of producing antibodies in relatively large quantities that have well-defined specificity [1].

\section{Supports for IAC}

There are several types of supports that can be utilized to place antibodies within columns for use in IAC. Traditional immunoaffinity supports have been based on low-performance materials such as carbohydrate-related media (e.g., agarose and cellulose) or synthetic organic supports (e.g., acrylamide polymers, copolymers or derivatives, polymethacrylate derivatives and polyethersulfone matrixes). TABLE 1 lists several commercial supports in these categories that can be used to immobilize antibodies for IAC. The low cost of these materials has made these supports popular for IAC applications involving target purification or offline immunoextraction. However, most of these materials can be used at only relatively low back pressures and are best suited for work under gravity flow or with a peristaltic pump. These supports also can have slow mass-transfer properties.

These disadvantages have limited the use of the low-performance immunoaffinity supports in applications requiring their direct use with HPLC. When antibodies are used within an HPLC column, the resulting method is referred to as HPIAC. Immunoaffinity supports that are used for HPIAC must be rigid and have higher efficiency than typical low-performance supports [30]. Examples of materials that have been used in HPIAC include derivatized silica [31], glass [32], azalactone beads [33], methacrylate polymeric supports [34] and polystyrene-based perfusion media [35].

In addition to good efficiency and mechanical stability, the ideal support for IAC should have low nonspecific binding and be easily modified for antibody attachment. Another item to consider for a porous material is the size of its pores for immobilization of antibodies and binding by antibodies to the target. Supports with small pores have the largest amount of total surface area, but much of this area may not be accessible for antibody immobilization [30]. By contrast, supports with larger pores do not have accessibility problems, but their lower surface area can result in small amounts of immobilized antibodies. As a result, the maximum coverage for antibodies is often observed for supports with pore sizes of 300-500 $\AA$, which is approximately three- to five-times the diameter of an antibody [36]. This size range is also suitable for the binding of immobilized antibodies to many small- or mediumsized targets (i.e., agents with sizes less than about 100-150 kDa), although larger pore sizes may be needed for larger targets. Other support materials that have recently been used in IAC are disks, fibers and monolithic rods [30,37]. Unique features offered by these newer support materials include their good mass-transfer and flow properties [18]. A general procedure for immobilizing antibodies onto monoliths can be seen in FIGURE 4.

\section{Antibody-immobilization methods}

Antibodies can be immobilized onto supports by using a variety of techniques that range from covalent attachment to adsorption-based methods. Of these techniques, those that make use of covalent attachment are the most common, but even these methods can range from the use of random attachment via amino or carboxyl groups to more site-selective immobilization approaches that make use of modified carbohydrate residues or thiol groups. The ideal situation in any of these immobilization methods is to have antibodies attached to the support in a way that does not affect the activity of the binding sites or the accessibility of these sites to their target compound [38]. 
Antibodies can be immobilized through free amine groups by using supports that have been activated with agents such as $N, N^{\prime}$-carbonyldiimidazole, cyanogen bromide, $N$ hydroxysuccinimide or tresyl chloride/tosyl chloride. Antibodies can also be immobilized through amine groups using a support that has been treated to produce reactive epoxy or aldehyde groups on its surface $[33,39,40]$. The use of amine groups is one of the easiest ways to immobilize antibodies but can cause a decrease in activity if the antibodies have some of these amine groups in their antigen-binding sites [41]. In addition, this approach can cause the antibodies to be immobilized in a random orientation, leading to steric hindrance and a decrease in binding efficiency $[42,43]$.

Antibodies or $F_{a b}$ fragments can be covalently linked to IAC supports through more siteselective methods. This can be achieved by utilizing the free sulfhydryl groups that are created when $F_{a b}$ fragments are generated. These groups can be used for immobilization by using techniques such as the divinylsulfone, epoxy, iodoacetyl/bromoacetyl, maleimide or tresyl chloride/tosyl chloride methods $[33,39,40]$. In addition, site-selective immobilization can be accomplished by coupling antibodies through the carbohydrate residues that are located in their $F_{c}$ regions. This process is carried out by first oxidizing the carbohydrate residues under mild conditions to generate aldehyde residues. These aldehyde groups are then reacted with a hydrazide- [44] or amine-containing support [33,39].

A third way antibodies can be immobilized onto supports is by using a secondary ligand to adsorb these antibodies. This can be accomplished by using antibodies that have been reacted with biotin or biotinylated, and then adsorbed to a support that contains immobilized avidin or streptavidin. The most popular biotinylation technique is to incubate antibodies with $N$-hydroxysuccinimide- $D$-biotin at $\mathrm{pH} 9$. The strong noncovalent linkage of biotin to strepavidin or avidin can then be used to immobilize these antibodies. These linkages have association equilibrium constants in the range of $10^{13}-10^{15} \mathrm{M}^{-1}[45,46]$ and can resist many types of elution conditions without dissociation. In addition, a modified version of avidin called neutravidin (from Pierce) can be used for the immobilization of biotinylated antibodies. If amine-based coupling of biotin to the antibodies is employed, the biotin can attach at or near the antibody's binding sites and cause a decrease in binding. There will also be random orientiation of the resulting biotinylated antibodies on the streptavidin support. These problems can instead be minimized by using hydrazide-biotin [47], which is reacted with the carbohydrate residues of antibodies after these regions have been oxidized under mild conditions to produce some aldehyde groups, as discussed in the previous paragraph.

Another approach for antibody immobilization utilizes the strong binding of protein A or protein $\mathrm{G}$ to the $F_{c}$ regions of many antibodies. Protein A and protein $\mathrm{G}$ are bacterial cell wall proteins that have strong binding for many types of antibodies under physiological conditions. However, if the $\mathrm{pH}$ of the surrounding solution is decreased to approximately $\mathrm{pH}$ $2-3$, this binding will be weakened and the retained antibodies can be eluted $[4,33,39]$. Protein A and protein G supports are useful when high antibody activity is needed and it is desirable to have frequent antibody replacement in an IAC column. Long-term reproducibility of the IAC binding capacity is possible when using protein A or protein $\mathrm{G}$ supports, but a much larger amount of antibodies will be needed than is required for traditional immobilization methods if the antibodies are eluted and replaced on a regular basis. If desired, protein A or protein $\mathrm{G}$ supports can be prepared with a permanent coating of antibodies by cross-linking the antibodies to the immobilized protein A or protein $\mathrm{G}$ by using carbodiimide [48] or dimethyl pimelimidate [49,50].

\section{Application \& elution conditions}

The application and elution conditions are another important set of factors to consider in the design and use of an IAC method. The application buffer used in IAC is generally chosen 
for its ability to promote fast and efficient binding of the desired analyte or target compound to the immobilized antibodies. Optimum binding for antibodies typically occurs under physiological conditions, so IAC generally makes use of a neutral $\mathrm{pH}$ buffer (i.e., $\mathrm{pH} 7.0$ 7.4). Under these conditions, the equilibrium constants for antibody binding is usually in the range of $10^{6}-10^{12} \mathrm{M}^{-1}$. Due to this strong binding between the antibody and its target, isocratic elution is often not feasible unless the IAC method is using low-affinity antibodies (i.e., those with association equilibrium constants of less than $10^{6} \mathrm{M}^{-1}$ ) [51-53].

The elution conditions for IAC need to allow for fast elution of the analyte while still allowing later regeneration of the immobilized antibodies. The need for fast but reversible binding and regeneration is especially important when an IAC column is to be used for a large number of samples. Elution is often carried out by temporarily lowering the effective strength of antibody binding to the target. The most-common approaches for elution in IAC include changing the mobile phase $\mathrm{pH}$ or adding a chaotropic agent to the mobile phase. Other, less-common IAC elution methods include adding a competing agent, organic modifier or denaturing agent to the mobile phase, or changing the temperature of the column during elution [54]. Usually the elution buffer is applied in a step gradient, but gradual or nonlinear gradients can be used as well [1,2,4]. FIGURE 5 shows a common scheme by which an IAC column can be used to selectively bind and elute analytes from a sample.

Changing the mobile phase $\mathrm{pH}$ is the most popular method for eluting retained compounds from IAC columns. This approach is usually conducted by applying an acidic buffer $(\mathrm{pH} 1-$ 3 ) to the column. Alkaline elution conditions have been used in conjunction with lowperformance IAC supports [55,56], but cannot be used with common HPIAC supports, such as silica or glass beads, due to the instability of these supports at a $\mathrm{pH}$ greater than 8.0 [2]. One difficulty with changing the $\mathrm{pH}$ of the mobile phase is the possibility of denaturing the immobilized antibodies or any retained compounds that are susceptible to variations in $\mathrm{pH}$. However, many IAC columns have been shown to be quite stable when moderate $\mathrm{pH}$ changes in the range of 7.0-7.5 to $2.5-3.0$ are used for elution [1,2].

To avoid denaturing effects that are caused by lowering the $\mathrm{pH}$, the elution of retained compounds in IAC can alternatively be performed by adding chaotropic agents such as thiocyanate $\left(\mathrm{SCN}^{-}\right)$, trifluoroacetate $\left(\mathrm{CF}_{3} \mathrm{COO}^{-}\right)$, perchlorate $\left(\mathrm{ClO}_{4}{ }^{-}\right)$, iodide $\left(\mathrm{I}^{-}\right)$or chloride $\left(\mathrm{Cl}^{-}\right)$to the elution buffer. The elution strength of these agents follows the approximate order $\mathrm{SCN}^{-}>\mathrm{CF}_{3} \mathrm{COO}^{-}>\mathrm{ClO}_{4}{ }^{-}>\mathrm{I}^{-}>\mathrm{Cl}^{-}$. These agents are typically used at concentrations of 1.5-8 $\mathrm{M}$ and have been shown to be effective in dissociating highaffinity antibody-antigen complexes [57]. When an organic modifier is used in the mobile phase, care must be taken to ensure that the concentration of the organic additive does not permanently denature the antibodies. When methanol or other organic modifiers are used, the capacity of the immunoaffinity column has been shown to decrease. This denaturation is not irreversible, but kinetic regeneration can take a few days [54]. In one study, an anticlenbuterol immunoaffinity column was regenerated 20-times after offline elution with 2 $\mathrm{ml}$ of ethanol $80 \%$ in water [58]. However, this column was shown to lose half its activity over these 20 regenerations. Therefore, if harsh elution conditions are required, the capacity of the immunoaffinity column should be much larger than the actual amounts of analyte that are to be measured or isolated.

\section{Formats \& applications of IAC}

Immunoaffinity chromatography is a powerful technique that can selectively isolate a given compound from complex samples. As a result, many formats utilizing IAC have involved preparative applications or selective analyses. IAC has also been used with both direct and 
indirect detection methods and has been coupled with other methods such as HPLC, GC, MS and CE. Each of these formats will be discussed in more detail in the following sections.

\section{On/off elution \& direct detection methods}

Preparative applications generally use the on/off mode of IAC, as shown in FIGURE 5. This format can also be used with direct detection for chemical analysis. In the on/off mode, a sample is applied to the IAC column in the presence of an application buffer. As the sample is applied to the column, only the analyte and closely-related compounds are retained by the column, while other sample components pass through non-retained. After the analyte has been bound to the column and other materials have been washed away, an elution buffer is applied and the analyte is eluted. After this elution step, the application buffer is reapplied to the column to allow for regeneration of the antibodies prior to another sample application.

The on/off mode of IAC is commonly used in biochemistry and other fields for the selective purification of target compounds from complex samples. Compounds that have been isolated by this approach include proteins, glycoproteins, carbohydrates, lipids, bacteria, viral particles, drugs and environmental agents $[1,3,4,8-12]$. This mode can also be used for the direct detection of an analyte by placing a suitable detector after the IAC column [1,2]. For this type of application, the analyte must be present at relatively high concentration and be eluted in a sharp, well-defined peak that allows a good detection limit. Depending on the desired level of detection, UV/visible absorbance, fluorescence and MS have all been used for detecting analytes in the on/off mode of IAC. Specific examples of analytes that have been measured by this approach include human serum albumin $[59,60]$, recombinant tissuetype plasminogen activator [61], recombinant antithrombin III [61], IgG [59,62],

Escherichia coli [63], isoproturon [64], phenylurea herbicides [64,65], benzidine [66], dichlorobenzidine [66], aminoazobenzene [66], azo dyes [66], triazine [65], diethylstilbestrol [67], acetylcholinesterase [68], transferrin [69] and insulin [70].

\section{Immunoextraction \& immunodepletion}

When IAC is used to remove a specific analyte or group of analytes from a sample prior to analysis by a second analytical method, this approach is referred to as immunoextraction $[2,15,71]$. In contrast to the on/off method discussed in the previous section, immunoextraction is coupled with a second analytical method such as LC.

Immunoextraction can be carried out either offline or online with the second analytical method. In the offline mode, antibodies are typically immobilized onto a low-performance support and packed into a small disposable syringe or SPE cartridge. Samples are then applied through the affinity support, which binds the analytes of interest while other sample components are washed away. An elution buffer is then passed through the affinity support to elute the extracted analytes. In addition to removing undesirable sample components, immunoextraction can allow for analyte concentration. In fact, by applying a larger sample volume to the immunoaffinity support (as long as column capacity is not exceeded), more analyte can be made available for detection by the second analytical method due to the essentially irreversible binding of the analyte to the antibodies under typical application conditions [72-74]. Just as in traditional SPE methods, in offline IAC the eluted fraction can be collected, dried down, and dissolved in a solvent more suitable for analysis. If necessary, the sample can also be derivatized prior to analysis. Offline immunoextraction coupled with other methods has been used in the analysis of urine, food, water and soil extracts. Examples of analytes that have been examined by this approach include $\alpha_{1}$-anti-trypsin, atrazine, benzylpenicilloyl-peptides, bovine serum albumin, carbendazim, chloramphenicol, cortisol, clenbuterol and phenytoin, among others [1,2]. 
A related method that uses IAC is immunodepletion. In immunodepletion, an antibody column is used to remove abundant analytes from a complex sample prior to using a second method of analysis for the minor sample components. Typically, this method is used to remove high- and mid-abundance proteins from serum samples prior to the analysis of lowabundance proteins, as is often required in proteomics. In contrast to other methods that can be used to remove high- and mid-abundance proteins (e.g., precipitation, SPE, ultracentrifugation, molecular-weight separation and pI separation), immunodepletion can provide highly selective depletion of multiple high-abundance proteins simultaneously [7580].

\section{Hybrid IAC methods}

The on/off mode of IAC can also be used for online analytical applications. In this format, IAC is directly coupled to a second analytical technique for analysis. By directly combining immunoextraction with a second analytical method, such as HPLC, sample pretreatment can be automated. IAC is often coupled with reversed-phase (RP)LC [2,13,15], but methods in which IAC has been coupled with size exclusion, ion-exchange chromatography [81], CE [82-86], MS [87], GC [88,89] and microfluidic devices [14,90] have also been reported.

One reason immunoextraction is commonly coupled with RPLC is due to the widespread use of RPLC in chemical separations. In addition, the elution buffer used in IAC is an aqueous solution, which acts as a weak mobile phase for RP columns. Online immunoextraction coupled with RPLC has been used to measure compounds in food extracts [91], bodily fluids [92-99], cell extracts [100] and environmental samples [74,101]. An example of an HPLC system which allows for the combination of immunoextraction with RPLC is shown in FIGURE 6.

\section{Competitive binding assays}

Another way in which IAC can be used as an analytical tool is in an immunoassay format. This approach is known as a chromatographic immunoassay or flow-injection immunoassay. One general type of chromatographic immunoassay is a competitive binding assay, in which a signal is generated as the analyte competes with some labeled species for antibody binding sites.

The most common type of competitive binding immunoassay in IAC is the simultaneous injection immunoassay. A schematic diagram of this format is shown in FIGURE 7. In this method, a sample is mixed with a labeled analog of the analyte and applied to a column that contains a limited amount of immobilized antibodies. The limited amount of antibodies causes the labeled analog $\left(A^{*}\right)$ and the analyte $(A)$ to compete for binding sites. Due to the presence of this competition, the amount of labeled analog that is detected in the bound and/ or retained fractions is affected by the presence of analyte [20]. Typical calibration curves are prepared by plotting the relative response of the labeled analog, $B / B_{o}$, versus the concentration of analyte in the sample, where $B$ is the amount of labeled analog bound in the presence of a given amount of analyte and $B_{o}$ is the amount of labeled analog bound in the absence of any analyte. This type of calibration curve will have a maximum value of 1 when no analyte is present and should approach 0 at high analyte concentration, assuming there is no non-specific binding between the labeled analog and the column. A large variety of analytes have been measured by using simultaneous injection competitive binding immunoassays (TABLE 2) [102-131]. Factors that affect the response of these methods include the relative amount of analyte applied to the column, the flow rate and the amount of labeled analog used in the experiment $[132,133]$. 
A second type of competitive binding immunoassay is the sequential injection immunoassay [20]. As shown in Figure 8, this method differs from the simultaneous injection immunoassay format in that the sample is injected onto the column followed by a later injection of label analog. A calibration curve is again generated by plotting the relative response $\left(B / B_{o}\right)$ versus the analyte concentration. The sequential injection binding assay has one important advantage over the simultaneous injection format in that the labeled analog never comes into contact with the analyte, which means sample matrix effects during the detection of the labeled analog can be eliminated. This feature allows for improved reproducibility, a wider range of detection formats and lower background signals. Several applications of sequential injection immunoassay applications can be seen in TABLE 3 [134-144]. The sequential injection format tends to give lower LOD than the simultaneous format, because the analyte has a better chance of binding to the column in this format. However, the simultaneous injection format has higher upper LOD and a wider dynamic range [145]; this wider dynamic range is a result of the increased ability of the analyte to compete with the labeled analog when they are applied to the immunoaffinity column at the same time.

A third type of competitive binding immunoassay is the displacement immunoassay, as illustrated in FIGURE 9 [20]. In this method, an IAC column is first saturated with a labeled analog of the desired analyte. Sample is then injected onto this column and displaces any labeled analog that is momentarily free in solution. This displaced analog is then eluted from the column and gives a response that is proportional to the amount of analyte in the sample. As long as enough labeled analog remains bound to the column to give a consistent and measurable signal, several samples can be injected onto the IAC column before this column must be regenerated [146]. To help ensure enough labeled analog is present, IAC columns with large capacities are often employed for this format. Additionally, the stability of the signal depends on the rate of dissociation of the labeled analog from the immobilized antibodies [146,147]. When performing displacement immunoassays, slow flow rates tend to increase the displacement effect because longer times of contact between the sample and column allow for more labeled analog to dissociate from the immobilized antibodies. Several applications for displacement assays can be seen in TABLE 4 [146-152].

\section{Noncompetitive immunoassays}

Noncompetitive immunoassays are another group of immunoassays that use indirect detection. These assays are often referred to as immunometric methods. In these methods, there is no competition between the analyte and other substances. Two types of noncompetitive immunoassays have been used in IAC: sandwich immunoassays and one-site immunometric assays.

Sandwich immunoassays utilize two different antibodies that bind the same analyte. One of the antibodies is immobilized onto a solid support and is used to extract the analyte from samples. A second, labeled, antibody is either mixed with the sample prior to application or applied to the column directly after the sample is applied to the IAC column. Once the analyte is 'sandwiched' between the two antibodies, an elution buffer is applied to elute the analyte and labeled antibodies. The labeled antibodies can then be detected and give a response that is directly proportional to the amount of retained analyte. A typical scheme for this type of assay is given in FIGURE 10. When the sample and labeled antibodies are mixed prior to application onto the column, better detection limits can be obtained than when sequential injection of the sample and labeled antibodies is employed, because there is more effective binding between the labeled antibody and analyte. A calibration curve for sandwich immunoassays is constructed by plotting the relative response of the eluted labeled antibody against the amount of analyte in a sample and can give a linear response over a broad range of analyte concentrations $[2,20]$. 
Due to the direct relationship between the amount of analyte and the response in a sandwich immunoassay, plus the ability to use an excess of labeled antibodies to help promote good detection, this approach allows for better signal-to-noise ratios and lower limits of detection than competitive binding immunoassays [20]. Sandwich immunoassays also tend to be more selective than competitive binding immunoassays, because two types of antibodies are used for analyte binding and detection instead of one [153]. In general, low flow rates are desirable to allow sufficient time for analyte-antibody complexes to bind to an IAC column in this format. In addition, columns that can effectively capture the antibody-analyte complex with low nonspecific binding are best for sandwich immunoassay development. The main disadvantage of the sandwich immunoassay is that only large analytes (e.g., large peptides, proteins and biomacromolecules) can be quantified by this approach because the analyte must be able to bind two antibodies simultaneously. One other disadvantage of this approach is the added cost of performing a sandwich immunoassay due to the need for two different antibodies per analyte. Examples of sandwich immunoassays that have been carried out by using IAC can be found in TABLE 5 [60,110,154-161].

The format for a one-site immunometric assay is provided in FIGURE 11 [20]. In this method, the sample is incubated with a known excess of labeled antibodies or $F_{a b}$ fragments that can bind to the analyte. This mixture is then applied to a column with an immobilized analog of the analyte, which is used to remove the excess and unbound labeled antibodies/ antibody fragments. The bound analyte-labeled antibodies elute in the nonretained fraction with the analyte and give a signal that is proportional to the amount of analyte in the original sample. Typically, calibration curves for one-site immunometric assays are created by plotting the relative response of the labeled antibody-analyte complex against the amount of analyte in the sample. To obtain a maximum signal in a one-site immunometric assay, the binding between the labeled antibodies and the analyte must reach equilibrium and the flow rate must allow for the capture of all the excess binding agents on the IAC column. The column should also have a binding capacity that exceeds the amount of binding agent that is applied between regeneration steps. Some advantages of one-site immunometric assays are that they can detect both large and small analytes, their signal is directly proportional to the amount of analyte and a multitude of elution conditions can be used with the immobilized analog columns. The main disadvantage of one-site immunometric assays is obtaining affinity ligands with the required activity and purity to create an assay in which all the excess agent binds to the affinity column and gives a low background signal [162]. Examples of reports that have utilized the one-site immunometric format in IAC are listed in TABLE 6 [163-178].

\section{Postcolumn immunodetection}

An IAC column can also be used to monitor the presence of a specific analyte as it elutes from another chromatographic column. This use of IAC is referred to as immunodetection. Immunodetection can be performed using either direct detection or indirect detection. Typically, a postcolumn reactor and an IAC column are attached to the exit of an analytical HPLC column as shown in FIGURE 12. As the analyte elutes, it is mixed with excess labeled antibody. The excess labeled antibodies are removed using an immobilized analog of the analyte column. Bound, labeled antibodies pass through the analog column and give a signal proportional to analyte concentration. Reviews of this technique can be found elsewhere $[2,164]$. When performing postcolumn immunodetection, it is especially important to ensure the eluant from the HPLC column is properly adjusted to allow for maximum antibody binding in the postcolumn reactor $(\mathrm{pH}$, ionic strength and removal/ minimization of organic modifiers). 


\section{Recent developments in IAC}

The development of IAC is ongoing and continues to be integrated with other analytical techniques, including CE and MS. Other new developments include ultrafast immunoaffinity $\mathrm{CE}$ and the use of antibodies in microanalytical systems.

When immobilized ligands are used in CE, the method is referred to as affinity electrophoresis [179]. Affinity ligands, such as antibodies, can be immobilized in CE capillaries by several methods, including physical entanglement in gels and covalently binding the ligand to the capillary wall, or polymers, frits or beads inside the capillary [82]. $\mathrm{CE}$ can also be used with antibodies/antibody fragments to quantitatively measure analytes by allowing CE to separate free analytes from analyte-antibody complexes [180]. These formats can be either competitive or noncompetitive, with noncompetitive formats giving better LOD [82]. CE immunoassays are utilized due to their ease of automation and their relatively fast separation of antibodies, analytes and/or antibody-analyte complexes [86]. Another advantage of CE immunoassays is that only small amounts of sample and reagents are used while still maintaining good LOD [181]. The best LOD in CE immunoassays are generally achieved when using laser-induced fluorescence detection or MS.

By combining IAC with MS (IAC-MS), a technique is produced that utilizes the selectively of antigen-antibody interactions and the sensitivity of MS. When performing online IACMS, the IAC elution buffer should contain only volatile buffer salts (e.g., ammonium acetate and ammonium formate) to avoid lowering ionization efficiency. In addition, methanol or acetonitrile is often added to the eluant prior to ionization to increase sensitivity. MALDI can use immobilized antibodies on the target to help extract desired compounds from a sample prior to analysis by MS [87].

Due to the speed and specificity of antibody-antigen interactions, IAC can also be used for very fast immunoextractions that often take less than a second to perform. Ultrafast immunoextraction has been used to quantify the free fraction for drugs and hormones in clinically related samples [182-184]. Measuring the free fractions of drugs and hormones in serum is often difficult for other methods, because any removal of the free fraction can perturb protein binding and cause additional drug or hormone to dissociate in the sample. In recent work, ultrafast immunoextraction conducted in less than a few hundred milliseconds has been used with both direct detection based on fluorescence and chromatographic immunoassays using a displacement format for detection of warfarin, phenytoin and thyroxine in protein and serum samples [182-184].

Owing to recent advances in microfabrication technologies, micro and ultramicro (nano) analytical systems can also be developed to utilize the specificity of antibodies [185]. These micrototal analysis systems can be engineered in a variety of formats, including the construction of microarrays which utilize several channels that can each separate multiple analytes all at once. Much like CE immunoassays, these systems need to use quite sensitive detectors, due to the small amounts of analyte that must be measured. One example of a micrototal analysis systems utilizing laser-induced fluorescence detection detected $\alpha$ fetoprotein $[186,187]$. More information on the combined use of IAC with microanalytical systems can be found in a review by Phillips [90].

\section{Conclusion}

This review has discussed how immunoaffinity chromatography can be used to extract compounds of interest from samples either for purification or quantification. The general parameters of antibodies and antibody production were discussed, along with various immobilization methods. Support materials and the characteristics needed for various types 
of analyses were also discussed. Multiple applications of IAC were presented including immunoextraction, immunodepletion and chromatographic immunoassays. In addition, combining other analysis methods with IAC was discussed including CE, MS and microanalytical systems.

\section{Future perspective}

Given the continued importance of antibodies as tools in examining biological samples, it is expected that the use of IAC and related methods will continue to grow in the field of bioanalysis. In the next 5-10 years it is anticipated that further work will continue in the creation of improved columns for IAC based on materials such as monolithic media or new chromatographic supports. The combined use of these IAC columns with MS, CE and other methods is also expected in fields such as proteomics, metabolomics and the highthroughput screening of biomarkers. It is also anticipated that applications of rapid immunoaffinity methods, chromatographic immunoassays and IAC columns in microanalytical systems will increase in such fields as the need increases for selective and fast methods for the examination of complex biological samples.

\section{Executive summary}

- Immunoaffinity chromatography (IAC) combines the use of LC with the specific binding of antibodies or related agents.

- IAC can be used in specific assays for a particular target or for purification and concentration of analytes prior to further examination by another technique.

- Factors to consider in the development of an IAC method include the supports and immobilization methods used for antibodies and the selection of application and elution conditions for the resulting columns.

- Applications of IAC include its use in purification, immunodepletion, direct sample analysis, chromatographic immunoassays and combined analysis methods.

- Recent developments of IAC include its use with CE or MS, ultrafast immunoextraction methods and microanalytical systems.

\section{KEY TERMS}

Immunoaffinity

chromatography

Immunodepletion

Chromatographic immunoassay

Ultrafast immunoextraction

Microanalytical system
Type of LC in which the stationary phase consists of an antibody or antibody-related reagent, which is used for the selective purification or analysis of a target compound

Use of an antibody column to remove abundant analytes from a complex sample prior to using a second method of analysis for minor sample components

Use of immunoaffinity chromatography as an analytical tool is in an immunoassay format

Type of immunoextraction that is designed to operate on a time scale that is typically less than a second

System produced by using microfabrication or other techniques to provide a miniaturized device for chemical analysis 
Displacement immunoassay

Immunometric method

Immunodetection
Type of competitive binding immunoassay in immunoaffinity chromatography in which an antibody column is first saturated with a labeled analog of the desired analyte, with the sample then being injected to displace any labeled analog that is momentarily free in solution

Type of immunoassay that uses indirect detection of the analyte through labeling with a binding agent rather than through competition with a labeled analyte analog

Use of an immunoaffinity column to monitor the presence of a specific analyte as it elutes from another chromatographic column

\section{Bibliography}

Papers of special note have been highlighted as:

- of interest

- of considerable interest

1. Hage, DS.; Phillips, TM. Chapter 6 Immunoaffinity chromatography. In: Hage, DS., editor. Handbook of Affinity Chromatography. NY, USA: Taylor \& Francis; 2006. . - Provides an indepth look at immunoaffinity chromatography, with an emphasis on method development, immunoextraction and sample analysis by immunoaffinity chromatography.

2. Hage DS. Survey of recent advances in analytical applications of immunoaffinity chromatography. J. Chromatogr. B 1998;715(1):3-28.. - Provides a good overall review of immunoaffinity chromatography and its analytical applications.

3. Calton GJ. Immunosorbent separations. Meth. Enzymol 1985;104:381-387. [PubMed: 6371448]

4. Phillips TM. High performance immunoaffinity chromatography. An introduction. LC Mag 1985;3:962-972.

5. D'allesandro G, Sofia F. The adsorption of antibodies from the sera of syphilitics and turburculosis patients. Z. Immunitats 1935;84:237-250.

6. Landsteiner K, Van Der Scheer J. Cross reactions of immune sera to azoproteins. J. Exp. Med 1936;63:325-339. [PubMed: 19870475]

7. Campbell DH, Luescher E, Lerman LS. Immunologic adsorbents. I. Isolation of antibody by means of a cellulose-protein antigen. Proc. Natl Acad. Sci. USA 1951;37:575-578. [PubMed: 16589016]

8. Weller MG. Immunochromatographic techiques - a critical review. Fres. J. Anal. Chem 2000;366:635-645.

9. Ehle H, Horn A. Immunoaffinity chromatography of enzymes. Bioseparation 1990;1:97-110. [PubMed: 1368167]

10. Nakajima M, Yamaguchi I. Purification of plant hormones by immunoaffinity chromatography. Kagaku to Seibutsu 1991;29:270-275.

11. Gallant SR. Immunoaffinity chromatography of proteins. Methods Mol. Biol 2004;251:103-109. [PubMed: 14704441]

12. Zolotarjova, N.; Boyes, B.; Martosella, J., et al. Immunoaffinity depletion of high-abundant proteins for proteomic sample preparation. In: Smejkal, GB.; Lazarev, A., editors. Separation Methods in Proteomics. FL, USA: CRC Press; 2006. p. 63-79.

13. de Frutos M, Regnier FE. Tandem chromatographic-immunological analyses. Anal. Chem 1993;65 17A-25A. . Provides a review of tandem separation methods that are based on immunoaffinity columns.

14. Peoples MC, Karnes HT. Microfluidic immunoaffinity separations for bioanalysis. J. Chromatogr. B 2008;866:14-25. 
15. Hage DS, Nelson MA. Chromatographic immunoassays. Anal. Chem 2001;73 198A-205A. . • Provides a general overview of chromatographic immunoassays.

16. Hage, DS.; Clarke, W. Immunoaffinity chromatography in clinical analysis. In: Aboul-Enein, HY., editor. Separation Techniques in Clinical Chemistry. NY, USA: Marcel Dekker; 2003. p. 361-387.

17. Nelson, MA.; Hage, DS. Environmental analysis by affinity chromatography. In: Hage, DS., editor. Handbook of Affinity Chromatography. NY, USA: Taylor \& Francis; 2006.

18. Jiang T, Mallik R, Hage DS. Affinity monoliths for ultrafast immunoextraction. Anal. Chem 2005;77:2362-2372. [PubMed: 15828768]

19. Hage DS, Rollag JG, Thomas DH. Analysis of atrazine and its degradation products in water by tandem high-performance immunoaffinity chromatography and reversed-phase liquid chromatography. ACS Symposium Series 1997;657:118-132.

20. Moser, AC.; Hage, DS. Chapter 29 Chromatographic immunoassays. In: DS, Hage, editor. Handbook of Affinity Chromatography. NY, USA: Taylor \& Francis; 2006. . - Gives a comprehensive description of the detection modes, labels and types of chromatographic immunoassays, including the theory of such methods.

21. Williams BAR, Diehnelt CW, Belcher P, et al. Creating protein affinity reagents by combining peptide ligands on synthetic DNA scaffolds. J. Am. Chem. Soc 2009;131:17233-17241. [PubMed: 19894711]

22. Benhar I. Design of synthetic antibody libraries. Expert Opin. Biol. Ther 2007;7:763-779. [PubMed: 17477812]

23. Lerner RA. Manufacturing immunity to disease in a test tube: the magic bullet realized. Angew. Chem. Int. Ed. Engl 2006;45:8106-8125. [PubMed: 17120282]

24. Donzeau M, Knappik A. Recombinant monoclonal antibodies. Methods Mol. Biol 2007;378:1531.

25. Boyle MDP, Langone JJ. A simple procedure to use whole serum as a source of either IgG-or IgMspecific antibody. J. Immunol. Meth 1980;32:51-58.

26. Kabat, EA.; Mayer, M. Experimental Immunochemistry. Springfield, IL, USA: 1961.

27. Eliasson M, Andersson R, Olsson A, Wigzell H, Uhlen M. Differential IgG-binding characteristics of staphylococcal protein A, streptococcal protein G, and a chimeric protein AG. J. Immunol 1989;142:575-581. [PubMed: 2521350]

28. Narhi LO, Caughey DJ, Horan TP, Kita Y, Chang D, Arakawa T. Fractionation and characterization of polyclonal antibodies using three progressively more chaotropic solvents. Anal. Biochem 1997;253:246-252. [PubMed: 9367510]

29. Kohler G, Milstein C. Continuous cultures of fused cells secreting antibody of predefined specificity. Nature 1975;256:495-497. [PubMed: 1172191]

30. Gustavsson, P.; Larsson, PO. Chapter 2 Support materials for affinity chromatography. In: Hage, DS., editor. Handbook of Affinity Chromatography. NY, USA: Taylor \& Francis; 2006.

31. Schiel JE, Mallik R, Soman S, Joseph KS, Hage DS. Applications of silica supports in affinity chromatography. J. Sep. Sci 2006;29:719-737. [PubMed: 16830485]

32. Phillips TM. Measurement of recombinant interferon levels by high performance immunoaffinity chromatography in body fluids of cancer patients on interferon therapy. Biomed. Chrom 1992;6:287-290.

33. Hage, DS. Chapter 10. In: Corradini, D., editor. Handbook of HPLC. Chapter 13. 2nd Edition. Boca Raton, FL, USA: Taylor \& Francis/CRC Press; 2010.

34. Mcconnell JP, Anderson DJJ. Determination of fibrinogen in plasma by high-performance immunoaffinity chromatography. J.Chromatogr 1993;615:67-75. [PubMed: 8340464]

35. Zou H, Zhang Y, Lu P, Krull IS. Perfusion immunoaffinity chromatography and its application in analysis and purification of biomolecules. Biomed. Chrom 1996;10:122-126.

36. Clarke W, Beckwith JD, Jackson A, Reynolds B, Karle EM, Hage DS. Antibody immobilization to high-performance liquid chromatography supports. Characterization of maximum loading capacity for intact immunoglobulin $\mathrm{G}$ and $\mathrm{F}_{\mathrm{ab}}$ fragments. J. Chromatogr. A 2000;888:13-22. [PubMed: 10949468] 
37. Mallik R, Hage DS. Affinity monolith chromatography. J. Sep. Sci 2006;29:1686-1704. [PubMed: 16970180]

38. Kim, H.; Hage, DS. Chapter 3 Immobilization methods for affinity chromatography. In: Hage, DS., editor. Handbook of Affinity Chromatography. NY, USA: Taylor \& Francis; 2006.

39. Hermanson, GT.; Mallia, AK.; Smith, PK. Immobilized Affinity Ligand Techniques. NY, USA: Academic Press; 1992. . Good overview of immobilization methods that can be used with antibodies and related ligands.

40. Larsson PO. High-performance liquid chromatography. Meth. Enzymol 1984;104:212-223. [PubMed: 6371445]

41. Kortt AA, Oddie GW, Iliadies P, Gruen LC, Hudson PJ. Nonspecific amine immobilization of ligand can be a potential source of error in Biacore binding experiments and may reduce binding affinities. Anal. Biochem 1997;253:103-111. [PubMed: 9356148]

42. Wilcheck M, Miron T. Limitations of $n$-hydroxy-succimide esters in affinity chromatography and protein immobilization. Biochemistry 1987;26:2155-2161. [PubMed: 19552008]

43. Phillips, TM. Isolation and recovery of biologically active proteins by high-performance immunoaffinity chromatography. In: Venter, CJ.; Harrison, LC., editors. The Use of HPLC in Receptor Biochemistry. NY, USA: John Wiley \& Sons; 1998. p. 129-154.

44. Ruhn PF, Garver S, Hage DS. Development of dihydrazide-activated silica supports for highperformance affinity chromatography. J. Chromatogr. A 1994;669:9-19. [PubMed: 8055106]

45. Bayer EA, Wilcheck M. The use of the avidin-biotin complex as a tool in molecular biology. Methods Biochem. Anal 1980;26:1-45. [PubMed: 7392958]

46. Hage, DS.; Bian, M.; Burks, R.; Karle, E.; Ohnmacht, C.; Wa, C. Chapter 5 Bioaffinity chromatography. In: Hage, DS., editor. Handbook of Affinity Chromatography. NY, USA: Taylor \& Francis; 2006.

47. O'Shannessy DJ, Quarles RH. Labeling of the oligosaccharide moieties of immunoglobulins. J. Immunol. Meth 1987;99:153-161.

48. Phillips TM, Queen WD, More NS, Thompson AM. Protein A-coated glass beads: universal support medium for high-performance immunoaffinity chromatography. J. Chromatogr 1985;327:213-219. [PubMed: 4030956]

49. Schneider C, Newman RA, Sutherland DR, Asser U, Greaves MF. A one-step purification of membrane proteins using a high efficiencey immunomatrix. J. Biol. Chem 1982;257:1076610769. [PubMed: 6955305]

50. Sisson TH, Castor CW. An improved method for immobilizing IgG antibodies on protein Aagarose. Immunol. Methods 1990;127:215-220.

51. Zopf D, Ohlson S, Dakour J, Wang W, Lundblad A. Analysis and purification of oligosaccharides by high-performance liquid affinity chromatography. Meth. Enzymol 1989;179:55-64. [PubMed: 2622361]

52. Dakour J, Lundblad A, Zopf D. Separation of blood group A-active oligosaccharides by highpressure liquid affinity chromatography using a monoclonal antibody bound to concanavalin a silica. Anal. Biochem 1987;161:140-143. [PubMed: 3034096]

53. Puchades R, Maquieira A. Recent developments in flow injection immunoanalysis. Crit. Rev. Anal. Chem 1996;26:195-218.

54. Delauney N, Pichon V, Hennion M-C. Immunoaffinity solid-phase extraction for the trace-analysis of low-molecular-mass analytes in complex sample matrices. J. Chromatogr. B 2000;745:15-37.. * Good review of immunoaffinity SPE and immunosorbents, including their characteristics, methods and uses.

55. Ibarra N, Caballero A, Gonzalez E, Valdes R. Comparison of different elution conditions for the immunopurification of recombinant hepatitis B surface antigen. J. Chromatogr. B 1999;735:271277.

56. Cong J, Thompson VF, Goll DE. Immunoaffinity purification of the calpains. Protein Exp. Purif 2002;25:283-290.

57. Sica V, Puca GA, Molinari M, Buonaguro FM, Bresciani F. Effect of chemical perturbation with sodium thiocyanate on receptor-estradiol interaction: a new exchange assay at low temperature. Biochemistry 1980;19 88-88. 
58. Lawrence JF, Menard C. Determination of clenbuterol in beef liver and muscle tissue using immunoaffinity chromatographic cleanup and liquid chromatography with ultraviolet absorbance detection. J. Chromatogr. B 1997;696:291-297.

59. Hage DS, Walters RR. Dual-column determination of albumin and immunoglobulin G in serum by high-performance affinity chromatography. J. Chromatogr 1987;386:37-49. [PubMed: 3104379]

60. Yoshikawa T, Terashima M, Katoh S. Immunoassay using HPLAC and fluorescence-labeled antibodies. J. Ferm. Bioeng 1995;80:200-203.

61. Beyer K, Reinecke M, Noe W, Scheper T. Immunobased elution assay for process control. Anal. Chim. Acta 1995;309:301-305.

62. Stoecklein W, Jaeger V, Schmid RD. Monitoring of mouse immunoglobulin G by flow-injection analytical affinity chromatography. Anal. Chim. Acta 1991;245:1-6.

63. Bouvrette P, Luong JHT. Development of a flow injection analysis (FIA) immunosensor for the detection of Escherichia coli. Int. J. Food Microbiol 1995;27:129-137. [PubMed: 8579984]

64. Delaunay-Bertoncini N, Pichon V, Hennion M-C. Comparison of immunoextraction sorbents prepared from monoclonal and polyclonal anti-isoproturon antibodies and optimization of the appropriate monoclonal antibody-based sorbent for environmental and biological applications. Chromatographia 2001;53:S224-S230.

65. Ferrer I, Hennion M-C, Barcelo D. Immunosorbents coupled online with liquid chromatography/ atmospheric pressure chemical ionization/mass spectrometry for the part per trillion level determination of pesticides in sediments and natural waters using low preconcentration volumes. Anal. Chem 1997;69:4508-4514.

66. Bouzige M, Legeay P, Pichon V, Hennion M-C. Selective on-line immunoextraction coupled to liquid chromatography for the trace determination of benzidine, congeners and related azo dyes in surface water and industrial effluents. J. Chromatogr. A 1999;846:317-329. [PubMed: 10420617]

67. Davoli E, Fanelli R, Bagnati R. Purification and analysis of drug residues in urine samples by online immunoaffinity chromatography/high-performance liquid chromatography/continuous-flow fast-atom-bombardment mass spectrometry. Anal. Chem 1993;65:2679-2685. [PubMed: 8238946]

68. Vanderlaan M, Lotti R, Siek G, King D, Goldstein M. Perfusion immunoassay for acetylcholinesterase: analyte detection based on intrinsic activity. J. Chromatogr. A 1995;711:2331. [PubMed: 7496493]

69. Janis LJ, Regnier FE. Dual-column immunoassays using protein G affinity chromatography. Anal. Chem 1989;61:1901-1906. [PubMed: 2802148]

70. Cole LJ, Kennedy RT. Selective preconcentration for capillary zone electrophoresis using protein G immunoaffinity capillary chromatography. Electrophoresis 1995;16:549-556. [PubMed: 7588525]

71. De Frutos M, Regnier FE. Tandem chromatographic-immunological analyses. Anal. Chem 1998;65 17A-25A.

72. Thomas DH, Beck-Westermeyer M, Hage DS. Determination of atrazine in water using tandem high-performance immunoaffinity chromatography and reversed-phase liquid chromatography. Anal. Chem 1994;66:3823-3829.

73. Hage, DS.; Rollag, JG.; Thomas, DH. Chapter 10. In: Aga, DS.; Thurman, EM., editors. Immunochemical Technology for Environmental Applications. DC, USA: ACS Press; 1997.

74. Rollag JG, Beck-Westermeyer M, Hage DS. Analysis of pesticide degradation products by tandem high-performance immunoaffinity chromatography and reversed-phase liquid chromatography. Anal. Chem 1996;68:3631-3637.

75. Hao P, Ren Y, Xie Y. Label-free relative quantification method for low-abundance glycoproteins in human serum by microtof-q. J. Chromatogr. B 2009;877:1657-1666.

76. Cellar NA, Karnoup AS, Albers DR, Langhorst ML, Young SA. Immunodepletion of high abundance proteins coupled on-line with reversed-phase liquid chromatography: a twodimensional LC sample enrichment and fractionation technique for mammalian proteomics. J. Chromatogr. B 2009;877:79-85.

77. Dowling P, O’Driscoll L, Meleady P, et al. 2-D difference gel electrophoresis of the lung squamous cell carcinoma versus normal sera demonstrates consistent alterations in the levels of ten specific proteins. Electrophoresis 2007;28:4302-4310. [PubMed: 18041032] 
78. Lai X, Bacallao RL, Blazer-Yost BLL, Hong D, Mason SB, Witzmann FA. Characterization of the renal cyst fluid proteome in autosomal dominant polycystic kidney disease (ADPKD) patients. Proteomics Clin. Appl 2008;2(7-8):1140-1152. [PubMed: 20411046]

79. Chromy BA, Gonzales AD, Perkins J, et al. Proteomic anaylsis of human serum by two dimensional differential gel electrophoresis after depletion of high-abundant proteins. J. Proteome Res 2004;3:1120-1127. [PubMed: 15595720]

80. Yu KH, Rustgi AK, Blair IA. Characterization of proteins in human pancreatic cancer serum using differential gel electrophoresis and tandem mass spectrometry. J. Proteome Res 2005;4:17421751. [PubMed: 16212428]

81. Kagel JR, Rossi DT, Nordblom GD, et al. Considerations in the development of a sensitive HPLC assay for human epidermal growth factors in human plasma. J. Pharm. Biomed. Anal 1995;13:1205-1213. [PubMed: 8562592]

82. Heegaard, NHH.; Schou, C. Chapter 26 Affinity ligands in capillary electrophoresis. In: Hage, DS., editor. Handbook of Affinity Chromatography. NY, USA: Taylor \& Francis; 2006.

83. Amundson LK, Siren H. Immunoaffinity CE in clinical analysis of body fluids and tissues. Electrophoresis 2007;28:99-113. [PubMed: 17149780]

84. Guzman NA, Phillips TM. Immunoaffinity CE for proteomic studies. Anal. Chem 2005;77 60A67A.

85. Guzman NA. Immunoaffinity capillary electrophoresis applications of clinical and pharmaceutical relevance. Anal. Bioanal. Chem 2004;378:37-39. [PubMed: 14618292]

86. Moser AC, Hage DS. Capillary electrophoresis-based immunoassays: principles and quantitative applications. Electrophoresis 2008;29:3279-3295. [PubMed: 18646279] . - Discusses various types of immunoassays that can be performed by capillary electrophoresis, including methods that make use of immunoaffinity supports.

87. Briscoe, CJ.; Clarke, W.; Hage, DS. Chapter 27 Affinity mass spectrometry. In: Hage, DS., editor. Handbook of Affinity Chromatography. NY, USA: Taylor \& Francis; 2006.

88. Dalluge J, Hankemeier T, Vreuls RJJ, Brinkman UAT. Online coupling of immunoaffinity-based solid-phase extraction and gas chromatography for the determination of s-triazines in aqueous samples. J. Chromatogr. A 1999;830:377-386. [PubMed: 10048199]

89. Farjam A, Vreuls JJ, Cuppen WJGM, Brinkman UAT, de Jong GJ. Direct introduction of largevolume urine samples into an on-line immunoaffinity sample pretreatment-capillary gas chromatography system. Anal. Chem 1991;63:2481-2487. [PubMed: 1763806]

90. Phillips, TM. Chapter 28 Microanalytical methods based on affinity chromatography. In: Hage, DS., editor. Handbook of Affinity Chromatography. NY, USA: Taylor \& Francis; 2006.

91. Newkirk DK, Benson RW, Howard PC, Churchwell MI, Doerge DR, Roberts DW. Online immunoaffinity capture, coupled with HPLC and electrospray ionization mass spectrometry, for automated determination of fumonisins. J. Agr. Food Chem 1998;46:1677-1688.

92. Itoh M, Kominami G. On-line immunoaffinity extraction followed by high-performance liquid chromatography and radioimmunoassay for a novel retinobenzoic acid, AM-80, in human plasma. J. Immunoassay Immunochemistry 2001;22:213-223.

93. Holtzapple CK, Buckley SA, Stanker LH. Determination of fluoroquinolones in serum using an on-line clean-up column coupled to high-performance immunoaffinity-reversed-phase liquid chromatography. J. Chromatogr. B 2001;754:1-9.

94. Creaser CS, Feely SJ, Houghton E, Seymour M. Immunoaffinity chromatography combined online with high-performance liquid chromatography-mass spectrometry for the determination of corticosteroids. J. Chromatogr. A 1998;794:37-43. [PubMed: 9491555]

95. Flurer CL, Novotny M. Dual microcolumn immunoaffinity liquid chromatography: an analytical application to human plasma proteins. Anal. Chem 1993;65:817-821. [PubMed: 8460833]

96. Farjam A, Brugman AE, Lingeman H, Brinkman UAT. On-line immunoaffinity sample pretreatment for column liquid chromatography: evaluation of desorption techniques and operating conditions using an anti-estrogen immuno-precolumn as a model system. Analyst 1991;116:891896. [PubMed: 1759718]

97. Radabaugh MR, Nemirovskiy OV, Misko TP, Aggarwal P, Mathews WR. Immunoaffinity liquid chromatography-tandem mass spectrometry detection of nitrotyrosine in biological fluids: 
development of a clinically translatable biomarker. Anal. Biochem 2008;380:68-76. [PubMed: 18539125]

98. Berna M, Schmalz C, Dufflin K, Mitchell P, Chambers M, Ackermann B. Online immunoaffinity liquid chromatography/tandem mass spectrometry determination of a type II collagen peptide biomarker in rat urine: investigation of the impact of collision-induced dissociation fluctuation on peptide quantitation. Anal. Biochem 2006;356:235-243. [PubMed: 16797470]

99. Hoos JS, Sudergat H, Hoelck J-P, et al. Selective quantitative bioanalysis of proteins in biological fluids by on-line immunoaffinity chromatography-protein digestion-liquid chromatography-mass spectrometry. J. Chromatogr. B 2006;830:262-269.

100. Roberts DW, Churchwell MI, Beland FA, Fang J-L, Doerge DR. Quantitative analysis of etheno-2'-deoxycytidine DNA adducts using on-line immunoaffinity chromatography coupled with LC/ES-MS/MS detection. Anal. Chem 2001;73:303-309. [PubMed: 11199982]

101. Nelson MA, Papastavros E, Dodlinger M, Hage DS. Environmental analysis by on-line immunoextraction and reversed-phase liquid chromatography: optimization of the immunoextraction/RPLC interface. J. Agr. Food Chem 2007;55:3788-3797. [PubMed: 17455948]

102. Garcinuno RM, Fernandez P, Perez-Conde C, Gutierrez AM, Camara C. Development of a fluoroimmunosensor for theophylline using immobilized antibody. Talanta 2000;52:825-832. [PubMed: 18968042]

103. Ren X. Flow injection fluoroimmunoassay for human transferrin using a protein A immunoreactor. Anal. Lett 1994;27:1067-1074.

104. Palmer DA, Fernandez-Hernando P, Miller JN. A model online flow injection fluorescence immunoassay using a protein a immunoreactor and Lucifer yellow. Anal. Lett 1993;26:25432553.

105. Martin-Esteban A, Fernandez P, Perez-Conde C, Gutierrez AM, Camara C. New fluorescence immunoassay for adrenocorticotropic hormone determination using flow injection analysis. Anal. Quim. Int. Ed 1996;92:37-40.

106. Palmer DA, Evans M, Miller JN, French MT. Rapid fluorescence flow injection immunoassay using a novel perfusion chromatographic material. Analyst 1994;119:943-947.

107. Rico CM, Fernandez MDP, Gutierrez AM, Conde MCP, Camara C. Development of a flow fluoroimmunosensor for determination of theophylline. Analyst 1995;120:2589-2591.

108. Turiel E, Fernandez P, Perez-Conde C, Gutierrez AM, Camara C. Flow-through fluorescence immunosensor for atrazine determination. Talanta 1998;47:1255-1261. [PubMed: 18967431]

109. Meyer, Uj; Zhi, Z-L.; Meusel, M.; Spener, F.; Loomans, E. Automated stand-alone flow injection immunoanalysis system for the determination of cephalexin in milk. Analyst 1999;124:16051610. [PubMed: 10746320]

110. de Frutos M, Paliwal SK, Regnier FE. Liquid chromatography based enzyme-amplified immunological assays in fused-silica capillaries at the zeptomole level. Anal. Chem 1993;65:2159-2163. [PubMed: 8372972]

111. Palmer DA, Edmonds TE, Seare NJ. Flow-injection immunosensor for theophylline. Anal. Lett 1993;26:1425-1439.

112. Wang Q, Luo G, Wang Y, Yeung WSB. Sandwich immunoassay for monoclonal antibody using protein $\mathrm{G}$ immunoaffinity capillary chromatography and diode laser induced fluorescence detection. J. Liq. Chrom. Rel. Tech 2000;23:1489-1498.

113. Mattiasson B, Borrebaeck C, Sanfridson B, Mosbach K. Thermometric enzyme linked immunosorbent assay: TELISA. Biochim. Biophys. Acta 1977;483:221-227. [PubMed: 329888]

114. Middendorf C, Schulze B, Freitag R, Scheper T, Howaldt M, Hoffmann H. Online immunoanalysis for bioprocess control. J. Biotech 1993;31:395-403.

115. Pollema CH, Ruzicka J, Christian GD, Lernmark A. Sequential injection immunoassay utilizing immunomagnetic beads. Anal. Chem 1992;64:1356-1361. [PubMed: 1503215]

116. Valencia-Gonzalez MJ, Diaz-Garcia ME. Flow-through fluorescent immunosensing of IgG. Ciencia 1996;4:29-40. 
117. Yang H-H, Zhu Q-Z, Qu H-Y, Chen X-L, Ding M-T, Xu J-G. Flow injection fluorescence immunoassay for gentamicin using sol-gel-derived mesoporous biomaterial. Anal. Biochem 2002;308:71-76. [PubMed: 12234465]

118. Pollema CH, Ruzicka J. Flow injection renewable surface immunoassay: a new approach to immunoanalysis with fluorescence detection. Anal. Chem 1994;66:1825-1831. [PubMed: 8030788]

119. Mecklenburg M, Lindbladh C, Li H, Mosbach K, Danielsson B. Enzymic amplification of a flowinjected thermometric enzyme-linked immunoassay for human insulin. Anal. Biochem 1993;212:388-393. [PubMed: 8214581]

120. Gonzalez-Martinez MA, Morais S, Puchades R, Maquieira A, Abad A, Montoya A. Development of an automated controlled-pore glass flow-through immunosensor for carbaryl. Anal. Chim. Acta 1997;347:199-205.

121. Gascon J, Oubina A, Ballesteros B, et al. Development of a highly sensitive enzyme-linked immunosorbent assay for atrazine. Performance evaluation by flow injection immunoassay. Anal. Chim. Acta 1997;347:149-162.

122. Katmeh MF, Godfrey AJM, Stevenson D, Aherne GW. Enzyme immunoaffinity chromatography - a rapid semi-quantitative immunoassay technique for screening the presence of isoproturon in water samples. Analyst 1997;122:481-486. [PubMed: 9246817]

123. Mattiasson B, Svensson K, Borrebaeck C, Jonsson S, Kronvall G. Non-equilibrium enzyme immunoassay of gentamicin. Clin. Chem 1978;24:1770-1773. [PubMed: 359194]

124. de Alwis U, Wilson GS. Rapid heterogeneous competitive electrochemical immunoassay for IgG in the picomole range. Anal. Chem 1987;59:2786-2789. [PubMed: 3434806]

125. Dreveny D, Seidl R, Gubitz G, Michalowski J. Development of solid-phase chemiluminescence immunoassays for digoxin comparing flow injection and sequential injection techniques. Analyst 1998;123:2271-2276. [PubMed: 10396801]

126. Hacker A, Hinterleitner M, Shellum C, Guebitz G. Development of an automated flow injection chemiluminescence immunoassay for human immunoglobulin G. Fres. J. Anal. Chem 1995;352:793-796.

127. Yap WT, Locascio-Brown L, Plant AL, Choquette SJ, Horvath V, Durst RA. Liposome flow injection immunoassay: model calculations of competitive immunoreactions involving univalent and multivalent ligands. Anal. Chem 1991;63:2007-2011. [PubMed: 1750702]

128. Locascio-Brown L, Plant AL, Chesler R, Kroll M, Ruddel M, Durst RA. Liposome-based flowinjection immunoassay for determining theophylline in serum. Clin. Chem 1993;39:386-391. [PubMed: 8448847]

129. Kamel R, Landon J, Forrest GC. A fully automated, continuous-flow radioimmunoassay for methotrexate. Clin. Chem 1980;26:97-100. [PubMed: 7356581]

130. He Z, Jin W. Capillary electrophoretic enzyme immunoassay with electrochemical detection for thyroxine. Anal. Biochem 2003;313:34-40. [PubMed: 12576055]

131. Schmalzing D, Nashabeh W, Fuchs M. Solution-phase immunoassay for determination of cortisol in serum by capillary electrophoresis. Clin. Chem 1995;41:1403-1406. [PubMed: 7656457]

132. Hage DS, Thomas DH, Beck MS. Theory of a sequential addition competitive binding immunoassay based on high-performance immunoaffinity chromatography. Anal. Chem 1993;65:1622-1630. [PubMed: 8328676]

133. Hage DS, Thomas DH, Chowdhuri AR, Clarke W. Development of a theoretical model for chromatographic-based competitive binding immunoassays with simultaneous injection of sample and label. Anal. Chem 1999;71:2965-2975. [PubMed: 10450148]

134. Lee M, Durst RA, Wong RB. Comparison of liposome amplification and fluorophor detection in flow-injection immunoanalyses. Anal. Chim. Acta 1997;354:23-28.

135. Scheper T, Brandes W, Maschke H, Ploetz F, Mueller C. Two FIA-based biosensor systems studied for bioprocess monitoring. J. Biotech 1993;31:345-356.

136. Brandes W, Maschke HE, Scheper T. Specific flow injection sandwich binding assay for IgG using protein A and a fusion protein. Anal. Chem 1993;65:3368-3371. [PubMed: 8297025] 
137. Kaneki N, Xu Y, Kumari A, Halsall HB, Heineman WR, Kissinger PT. Electrochemical enzyme immunoassay using sequential saturation technique in a 20-ml capillary: digoxin as a model analyte. Anal. Chim. Acta 1994;287:253-258.

138. Kramer P, Schmid R. Flow injection immunoanalysis (FIIA) - a new immunoassay format for the determination of pesticides in water. Biosens. Bioelectron 1991;6:239-243. [PubMed: 1883603]

139. Kramer PM, Schmid RD. Automated quasi-continuous immunoanalysis of pesticides with a flow injection system. Pest. Sci 1991;32:451-462.

140. Nilsson M, Haakanson H, Mattiasson B. Process monitoring by flow-injection immunoassay: evaluation of a sequential competitive binding assay. J. Chromatogr 1992;597:383-389. [PubMed: 1517342]

141. Nilsson M, Mattiasson G, Mattiasson B. Automated immunochemical binding assay (flowELISA) based on repeated use of an antibody column placed in a flow-injection system. J. Biotech 1993;31:381-394.

142. Liu H, Yu JC, Bindra DS, Givens RS, Wilson GS. Flow injection solid-phase chemiluminescent immunoassay using a membrane-based reactor. Anal. Chem 1991;63:666-669.

143. Lee M, Durst RA, Wong RB. Development of flow-injection liposome immunoanalysis (FILIA) for imazethapyr. Talanta 1998;46:851-859. [PubMed: 18967206]

144. Lee M, Durst RA. Determination of imazethapyr using capillary column flow injection liposome immunoanalysis. J. Agr. Food Chem 1996;44:4032-4036.

145. Nelson MA, Reiter WS, Hage DS. Chromatographic competitive binding immunoassays: a comparison of the sequential and simultaneous injection methods. Biomed. Chrom 2003;17:188 200.

146. Kusterbeck AW, Wemhoff GA, Charles PT, et al. A continuous flow immunoassay for rapid and sensitive detection of small molecules. J. Immunol. Meth 1990;135:191-197.

147. Whelan JP, Kusterbeck AW, Wemhoff GA, Bredehorst R, Ligler FS. Continuous-flow immunosensor for detection of explosives. Anal. Chem 1993;65:3561-3565.

148. Rabbany SY, Kusterbeck AW, Bredehorst R, Ligler FS. Effect of antibody density on the displacement kinetics of a flow immunoassay. J. Immunol. Meth 1994;168:227-234.

149. Wemhoff GA, Rabbany SY, Kusterbeck AW, Ogert RA, Bredehorst R, Ligler FS. Kinetics of antibody binding at solid-liquid interfaces in flow. J. Immunol. Meth 1992;156:223-230.

150. Kronkvist K, Loevgren U, Svenson J, Edholm L-E, Johansson G. Competitive flow injection enzyme immunoassay for steroids using a post-column reaction technique. J. Immunol. Meth 1997;200:145-153.

151. Charles PT, Conrad DW, Jacobs MS, Bart JC, Kusterbeck AW. Synthesis of a fluorescent analog of polychlorinated biphenyls for use in a continuous flow immunosensor assay. Bioconj. Chem 1995;6:691-694.

152. Cassidy SA, Janis LJ, Regnier FE. Kinetic chromatographic sequential addition immunoassays using protein A affinity chromatography. Anal. Chem 1992;64:1973-1977. [PubMed: 1416045]

153. Hage DS, Taylor B, Kao PC. Intact parathyroid hormone: performance and clinical utility of an automated assay based on high-performance immunoaffinity chromatography and chemiluminescence detection. Clin. Chem 1992;38:1494-1500. [PubMed: 1643722]

154. Johns MA, Rosengarten LK, Jackson M, Regnier FE. Enzyme-linked immunosorbent assays in a chromatographic format. J. Chromatogr. A 1996;743:195-206. [PubMed: 8817882]

155. Hayes MA, Polson NA, Phayre AN, Garcia AA. Flow-based microimmunoassay. Anal. Chem 2001;73:5896-5902. [PubMed: 11791558]

156. Wang Q, Wang Y, Luo G, Yeung WSB. Feasibility study of enzyme-amplified sandwich immunoassay using protein $\mathrm{G}$ capillary affinity chromatography and laser induced fluorescence detection. J. Liq. Chrom. Rel. Tech 2001;24:1953-1963.

157. Karube I, Matsunaga T, Satoh T, Suzuki S. A catalytic immunoreactor for the amperometric determination of human serum albumin. Anal. Chim. Acta 1984;156:283-287.

158. de Alwis WU, Wilson GS. Rapid sub-picomole electrochemical enzyme immunoassay for immunoglobulin G. Anal. Chem 1985;57:2754-2756. [PubMed: 4083488] 
159. Lee IH, Meyerhoff ME. Rapid flow-injection sandwich-type immunoassays of proteins using an immobilized antibody reactor and adenosine deaminase-antibody conjugates. Anal. Chim. Acta 1990;229:47-55.

160. Shellum C, Guebitz G. Flow-injection immunoassays with acridinium ester-based chemiluminescence detection. Anal. Chim. Acta 1989;227:97-107.

161. Hage DS, Kao PC. High-performance immunoaffinity chromatography and chemiluminescent detection in the automation of a parathyroid hormone sandwich immunoassay. Anal. Chem 1991;63:586-595. [PubMed: 2031560]

162. Oates MR, Clarke W, Zimlich AII, Hage DS. Optimization and development of a highperformance liquid chromatography-based one-site immunometric assay with chemiluminescence detection. Anal. Chim. Acta 2002;470:37-50.

163. Miller KJ, Herman AC. Affinity chromatography with immunochemical detection applied to the analysis of human methionyl granulocyte colony stimulating factor in serum. Anal. Chem 1996;68:3077-3082. [PubMed: 8797373]

164. Irth H, Oosterkamp AJ, Tjaden UR, van der Greef J. Strategies for online coupling of immunoassays to HPLC. Trends Anal. Chem 1995;14:355-361.

165. Oosterkamp AJ, Irth H, Beth M, Unger KK, Tjaden UR, van der Greef J. Bioanalysis of digoxin and its metabolites using direct serum injection combined with liquid chromatography and online immunochemical detection. J. Chromatogr. B 1994;653:55-61.

166. Irth H, Oosterkamp AJ, van der Welle W, Tjaden UR, van der Greef J. Online immunochemical detection in liquid chromatography using fluorescein-labeled antibodies. J. Chromatogr 1993;633:65-72.

167. Lindgren A, Emneus J, Marko-Varga G, Irth H, Oosterkamp A, Eremin S. Optimization of a heterogeneous non-competitive flow immunoassay comparing fluorescein, peroxidase and alkaline phosphatase as labels. J. Immunol. Meth 1998;211:33-42.

168. Kjellstrom S, Emneus J, Marko-Varga G. Flow immunochemical bio-recognition detection for the determination of interleukin-10 in cell samples. J. Immunol. Meth 2000;246:119-130.

169. Freytag JW, Lau HP, Wadsley JJ. Affinity-column-mediated immunoenzymometric assays: influence of affinity-column ligand and valency of antibody-enzyme conjugates. Clin. Chem 1984;30:1494-1498. [PubMed: 6432364]

170. Wilmer M, Trau D, Renneberg R, Spener F. Amperometric immunosensor for the detection of 2,4-dichlorophenoxyacetic acid (2,4-D) in water. Anal. Lett 1997;30:515-525.

171. Lovgren U, Kronkvist K, Backstrom B, Edholm L-E, Johansson G. Design of non-competitive flow injection enzyme immunoassays for determination of haptens. Application to digoxigenin. J. Immunol. Meth 1997;208:159-168.

172. Gunaratna PC, Wilson GS. Noncompetitive flow injection immunoassay for a hapten, $\alpha$ (difuoromethyl)ornithine. Anal. Chem 1993;65:1152-1157. [PubMed: 8503504]

173. Kaptein WA, Korf J, Cheng S, Yang M, Glatz JFC, Renneberg R. Online flow displacement immunoassay for fatty acid-binding protein. J. Immunol. Meth 1998;217:103-111.

174. Aref'ev AA, Vlasenko SB, Eremin SA, Osipov AP, Egorov AM. Flow-injection enzyme immunoassay of haptens with enhanced chemiluminescence detection. Anal. Chim. Acta 1990;237:285-289.

175. Silvaieh H, Schmid MG, Hofstetter O, Schurig V, Gubitz G. Development of enantioselective chemiluminescence flow- and sequential-injection immunoassays for $\alpha$-amino acids. J. Biochem. Biophys. Meth 2002;53:1-14. [PubMed: 12406581]

176. Locascio-Brown L, Choquette SJ. Measuring estrogens using flow injection immunoanalysis with liposome amplification. Talanta 1993;40:1899-1904. [PubMed: 18965868]

177. Wang R, Lu X, Ma W. Non-competitive immunoassay for $\alpha$-fetoprotein using micellar electrokinetic capillary chromatography and laser-induced fluorescence detection. J. Chromatogr. B 2002;779:157-162.

178. Bier FF, Jockers R, Schmid RD. Integrated optical immunosensor for s-triazine determination: regeneration, calibration and limitations. Analyst 1994;119:437-441.

179. Behnke B, Bayer E. Pressurized gradient electro-high-performance liquid-chromatography. J. Chromatogr. A 1994;680:93-98. 
180. Heegaard NHH, Kennedy RT. Antigen-antibody interactions in capillary electrophoresis. J. Chromatogr. B 2002;768:93-103.

181. Phillips TM, Wellner EF. Analysis of inflammatory biomarkers from tissue biopsies by chipbased immunoaffinity CE. Electrophoresis 2007;28 3401-3048.

182. Clarke W, Chowdhuri AR, Hage DS. Analysis of free drug fractions by ultrafast immunoaffinity chromatography. Anal. Chem 2001;73:2157-2164. [PubMed: 11393835]

183. Clarke W, Schiel JE, Moser AC, Hage DS. Analysis of free hormone fractions by an ultrafast immunoextraction/displacement immunoassay: studies using free thyroxine as a model system. Anal. Chem 2005;77:1859-1866. [PubMed: 15762597]

184. Ohnmacht CM, Schiel JE, Hage DS. Analysis of free drug fractions using near infrared fluorescent labls and an ultrafast immunoextraction/displacement assay. Anal. Chem 2006;78:7547-7556. [PubMed: 17073425]

185. Hou C, Herr AE. Clinically relevant advances in on-chip affinity-based electrophoresis and electrochromatography. Electrophoresis 2008;29:3306-3319. [PubMed: 18702056]

186. Kawabata T, Wada HG, Watanabe M, Satomura S. Electrokinetic analyte transport assay for $\alpha-$ fetoprotein immunoassay integrates mixing, reaction and separation on-chip. Electrophoresis 2008;29:1399-1406. [PubMed: 18384019]

187. Kagebayashi C, Yamaguchi I, Akinaga A, et al. Automated immunoassay system for AFP-13\% using on-chip electrokinetic reaction and separation by affinity electrophoresis. Anal. Biochem 2009;388:306-311. [PubMed: 19250915]

188. Durst RA, Locascio-Brown L, Plant AL. Automated liposome-based flow injection immunoassay system. GBF Monographs 1991;14:181-190. 


\section{Antigen-binding}

\section{site}

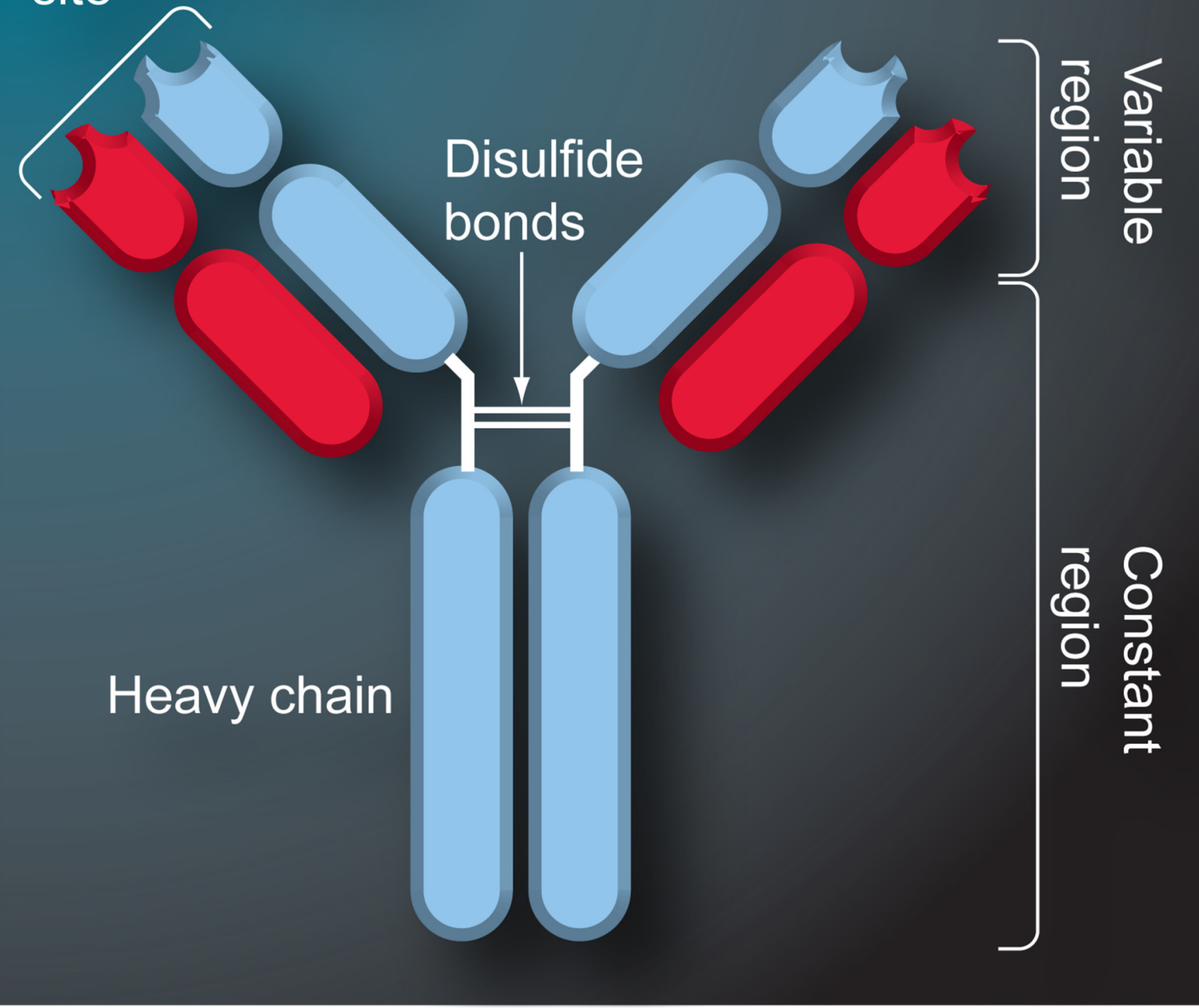

Figure 1. Typical structure of an IgG-class antibody

IgG-class antibodies consist of four polypeptide chains that are linked by disulfide bonds to create a ' $Y$ '-shaped structure with two identical binding sites. 

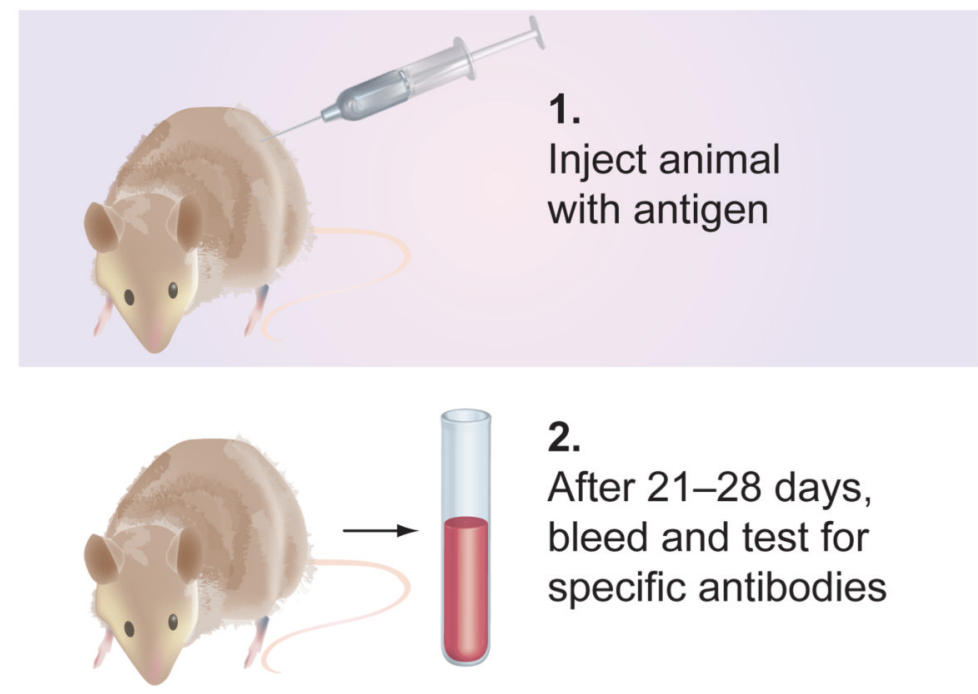

2.

After 21-28 days, bleed and test for specific antibodies
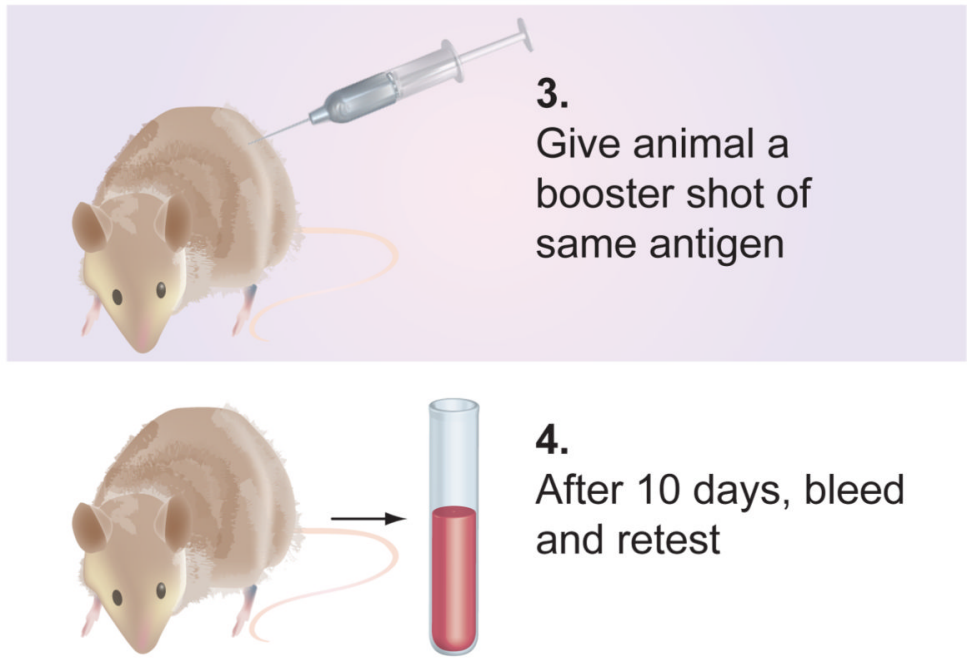

4.

After 10 days, bleed and retest

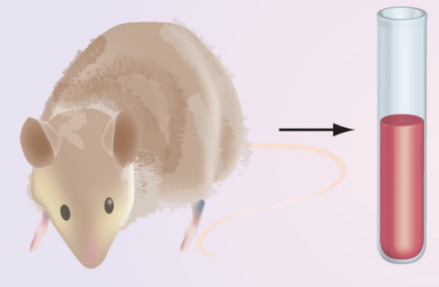

5.

If antibodies are being produced, then re-bleed 21 days later

Figure 2. Process for polyclonal antibody production

Figure adapted with permission from [1]. (C) Taylor and Francis CRC Press (2006). 


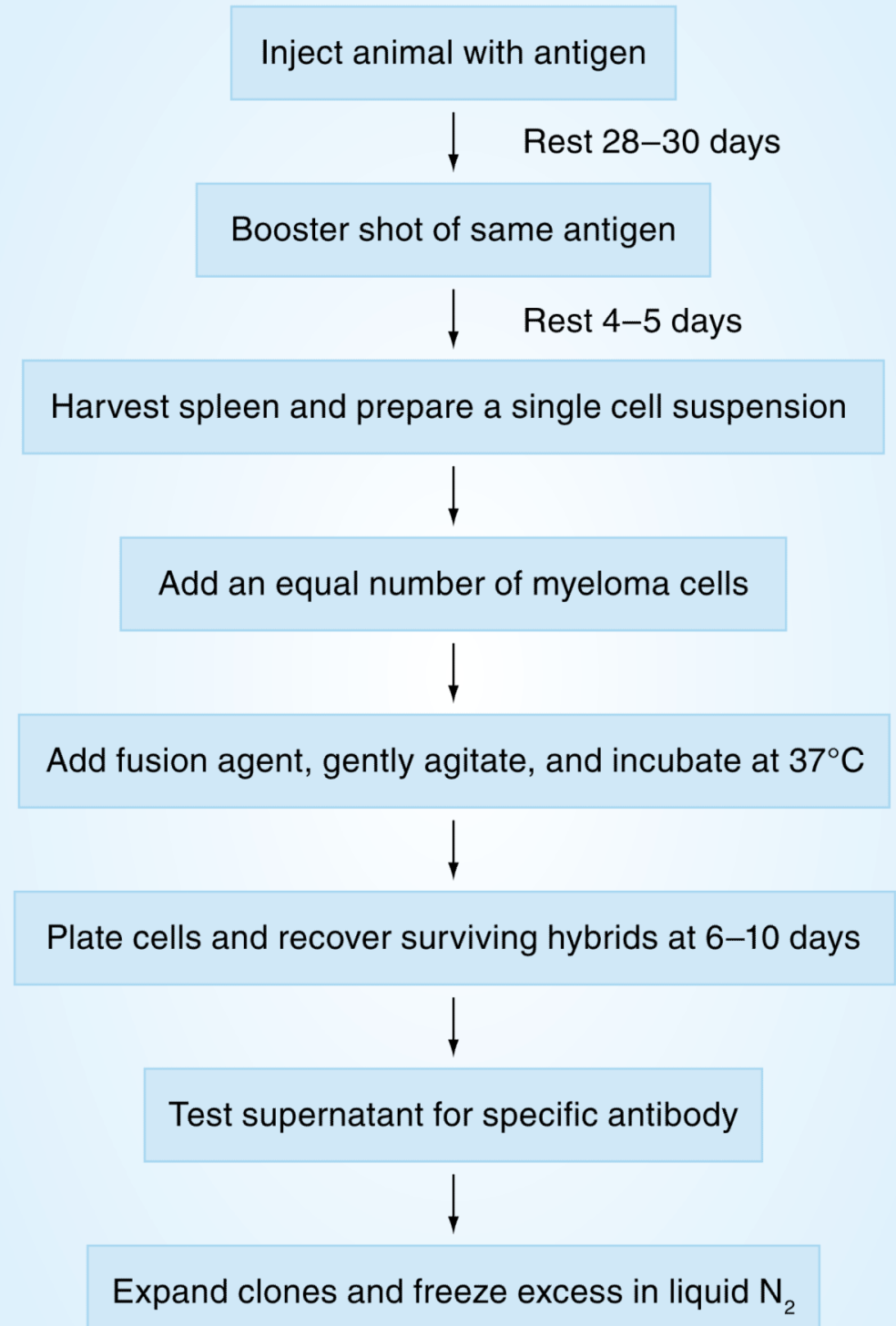

Figure 3. Process for monoclonal antibody production

Figure adapted from [1]. () Taylor and Francis CRC Press (2006). 

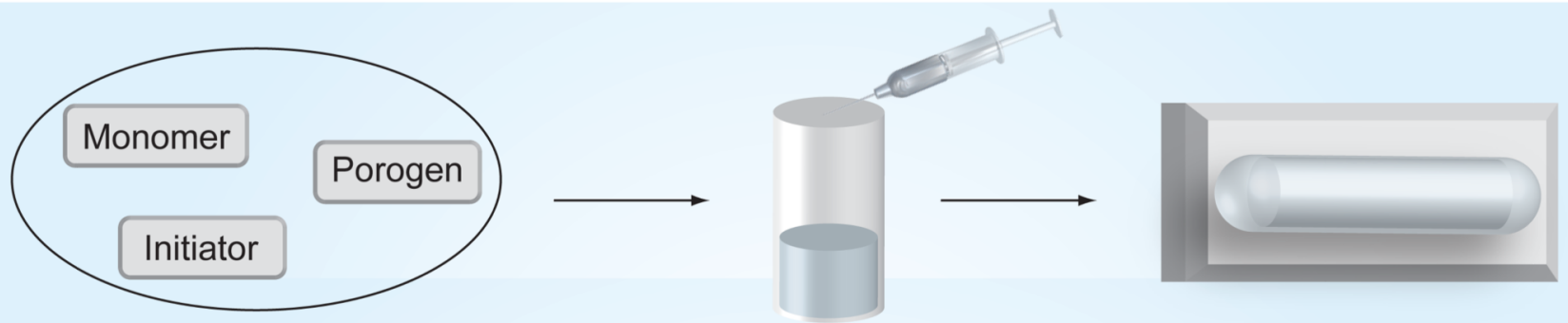

Weighing and mixing

Injection in a sealed column

Heat in water bath at $60^{\circ} \mathrm{C}$

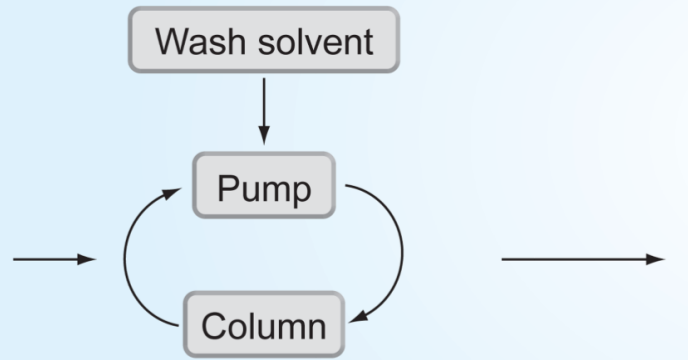

Activating agent

\section{Ligand solution}
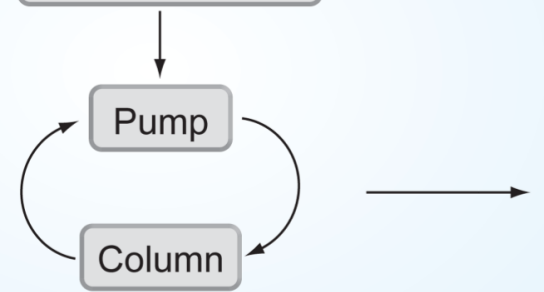

Activation of support

Immobilization of ligand

Figure 4. General procedure for immobilizing antibodies within a monolithic column Reproduced with permission from [18]. () American Chemical Society (2005). 


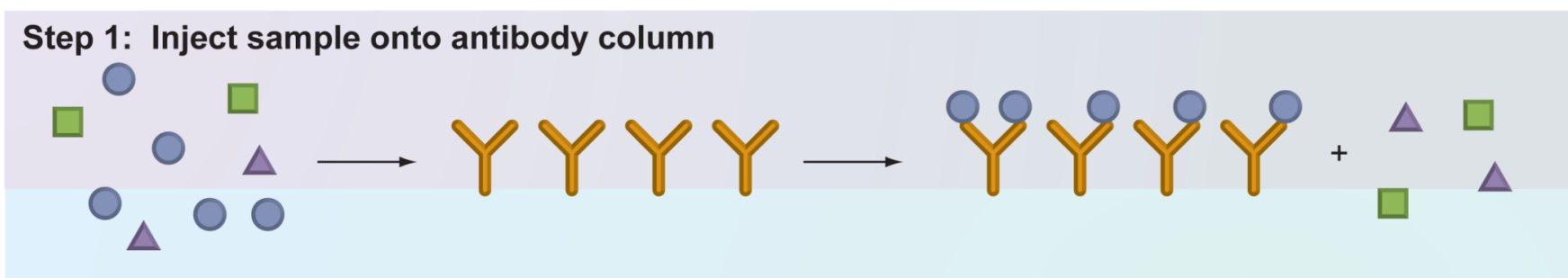

Step 2: Elution and detection of retained analyte

Elution buffer

$\longrightarrow$<smiles>[AlH2]</smiles>

Y

$Y$ Y Y

YYYY

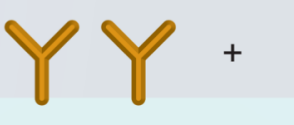

\section{Analyte}

\section{$\triangle$ Nonretained compounds}

Figure 5. Typical format in which a sample containing the analyte is applied to an immunoaffinity column and nonretained sample components are allowed to pass through The analyte is later eluted by disrupting the antibody-antigen interactions with an appropriate elution buffer. This on/off mode can be used for direct detection and/or purification of the analyte. 


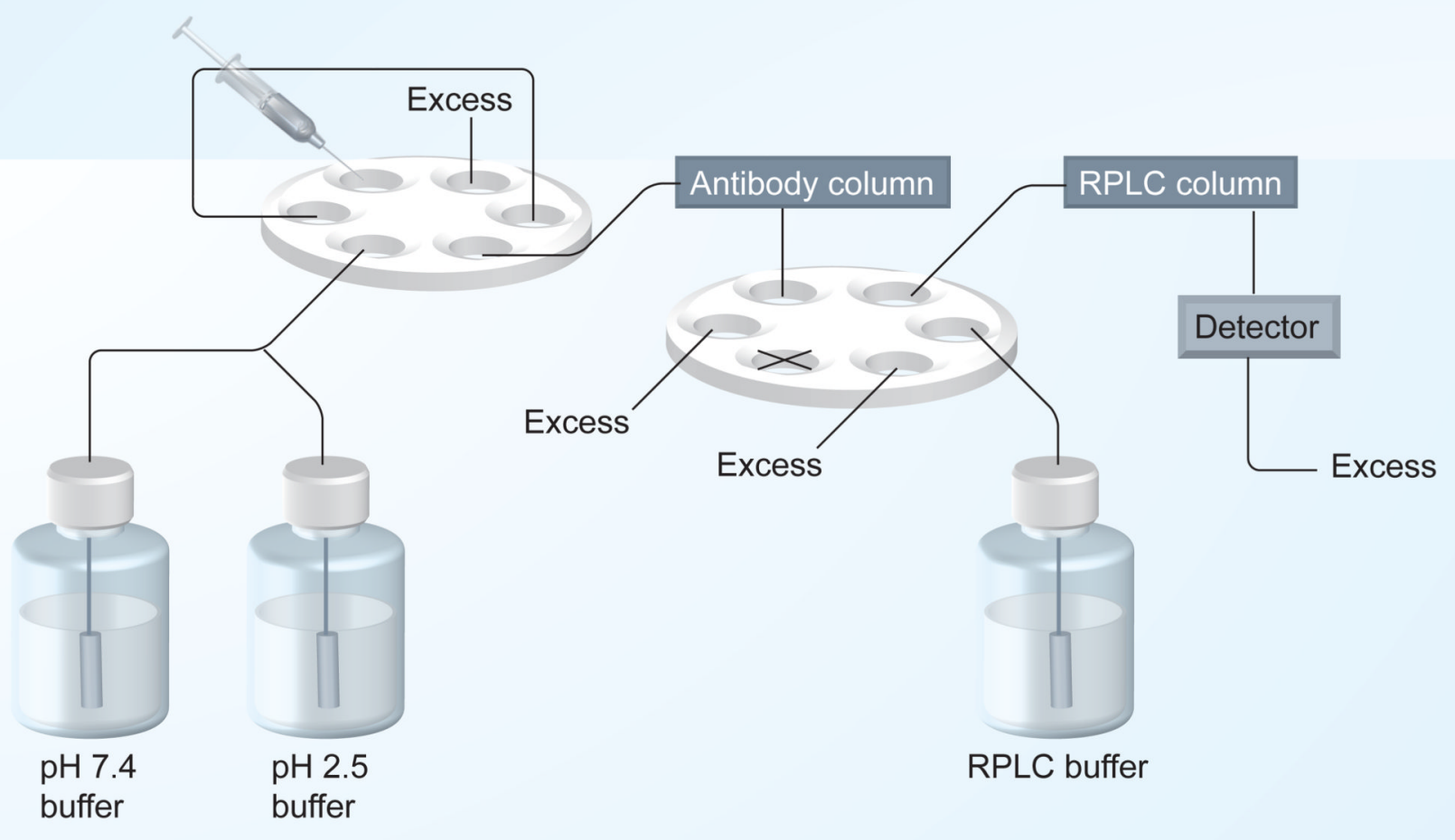

Figure 6. System for combining immunoaffinity chromatography with reversed-phase chromatography

An antibody column is used to extract or preconcentrate analytes from a sample prior to separation of these analytes using a reversed-phase column. This particular system has been used to measure virginiamycin in water samples with a LOD of $1 \mathrm{ppb}$.

RP: Reversed-phase.

Figure reproduced with permission from [ $\mathrm{C}_{\text {Arlson }} \mathrm{T}$, Moser $\left.\mathrm{AC}, \mathrm{U}_{\text {Npublished }} \mathrm{D}_{\text {ata }}\right]$. 


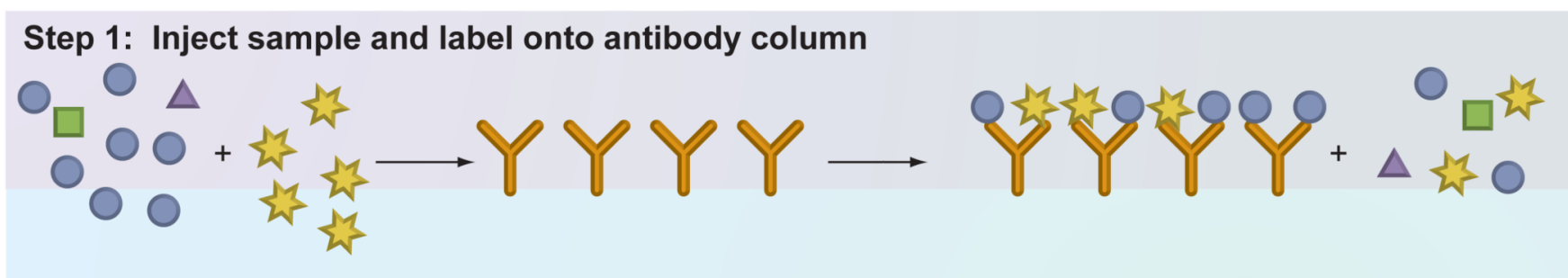

\section{Step 2: Elution and detection of retained analyte and labeled analog}

Elution buffer

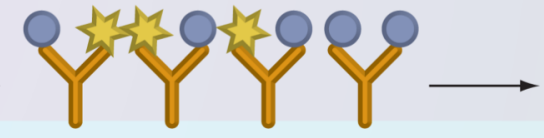

N $10+$

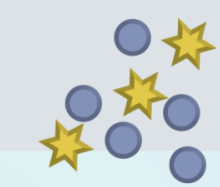

\section{Analyte $\quad \square$ Labeled analog $\square \Delta$ Nonretained compounds}

Figure 7. Simultaneous injection immunoassay format

In this type of competitive immunoassay, the sample and a labeled analog of the analyte are mixed and injected onto an immunoaffinity column. The labeled analog and analyte can bind to this column while other sample components pass through nonretained. The analyte and labeled analog are then eluted with an appropriate mobile phase/elution buffer. In this method the analyte concentration in the sample is inversely related to the amount of retained labeled analog that is detected. 


\section{Step 1: Inject sample onto antibody column}

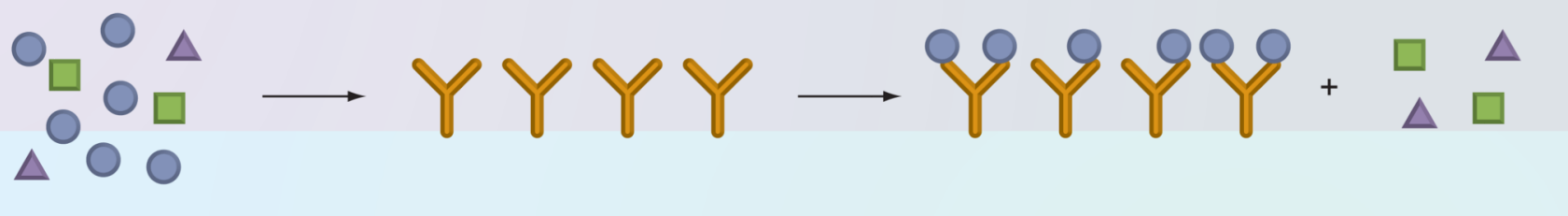

\section{Step 2: Inject labeled analog onto antibody support}

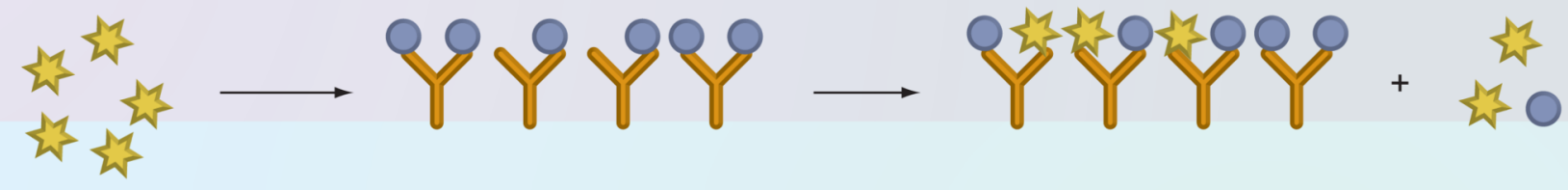

\section{Step 3: Detect excess label and/or elute label for detection (column regeneration)

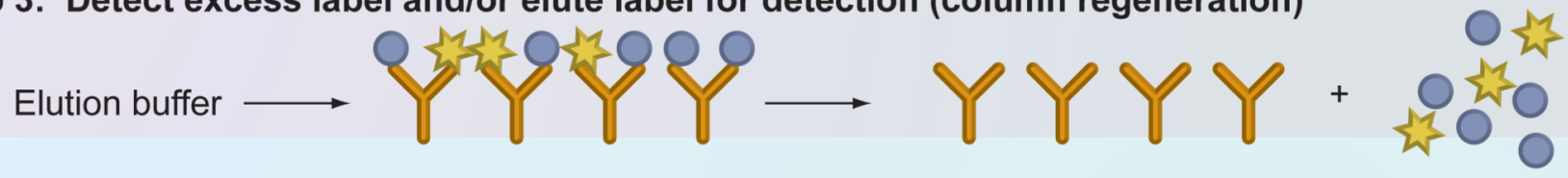 \\ Analyte $\quad$ Labeled analog $\square \Delta$ Nonretained compounds}

Figure 8. Sequential injection immunoassay format

In this format, the sample is applied onto an immunoaffinity column and the analyte is allowed to bind. A labeled analog of the analyte is then injected onto the same column and also allowed to bind to any remaining free antibody sites. An elution buffer is used to later remove both the retained analyte and labeled analog for the column. The amount of retained labeled analog will be inversely related to the amount of analyte that was in the original sample. 


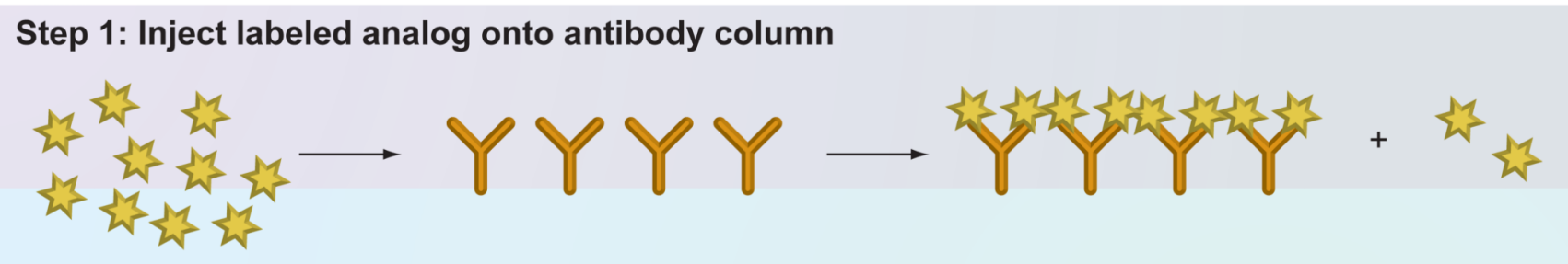

\section{Step 2: Inject sample onto antibody support}

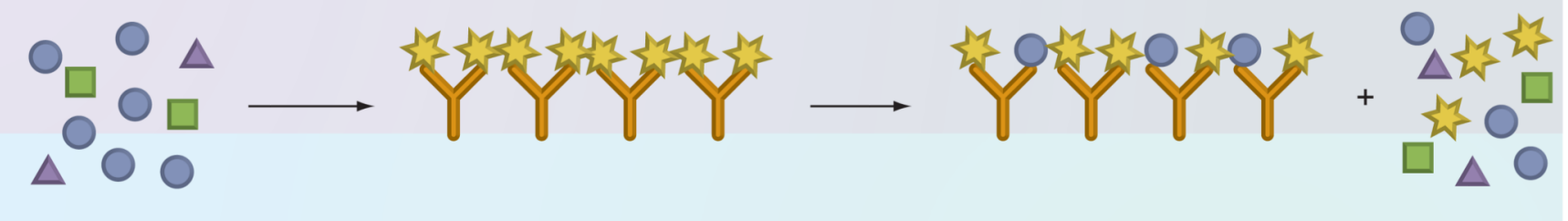

\section{Step 3: Detect displaced label and/or elute label for detection (column regeneration)

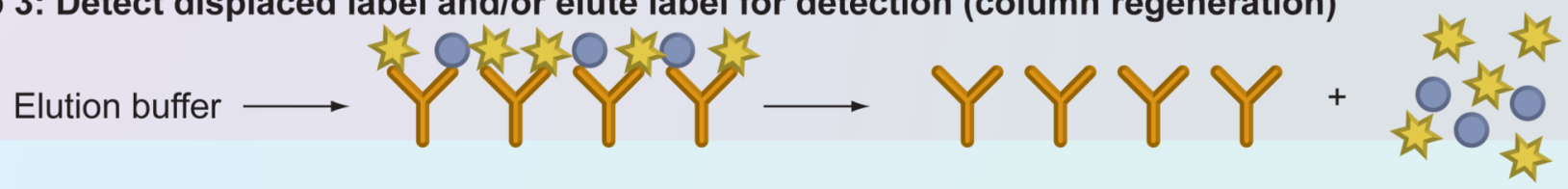 \\ Analyte $\quad$ Label $\square \Delta$ Nonretained compounds}

Figure 9. Displacement immunoassay format

In this type of competitive binding immunoassay, a labeled analog of the analyte is injected onto an immunoaffinity column. A sample is then injected onto the column and the analyte is allowed to displace some of the labeled analog. The size of the peak for the displaced label is directly related to the amount of analyte that was in the sample. 


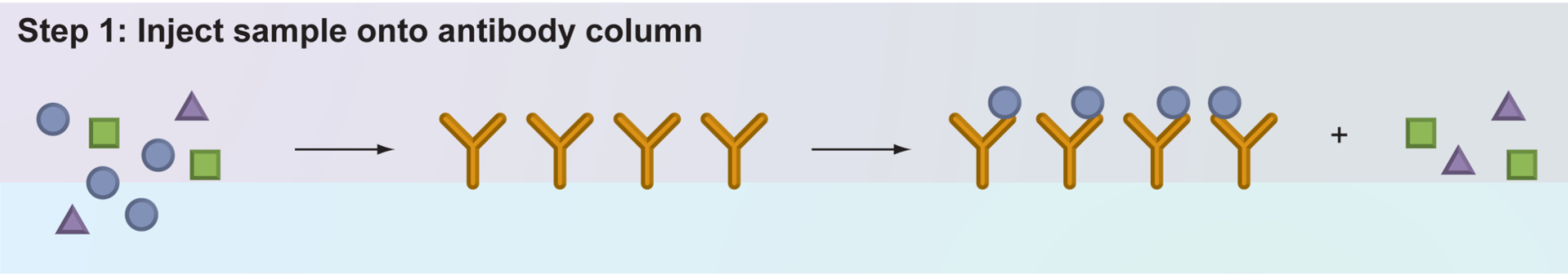

\section{Step 2: Inject label onto antibody support}
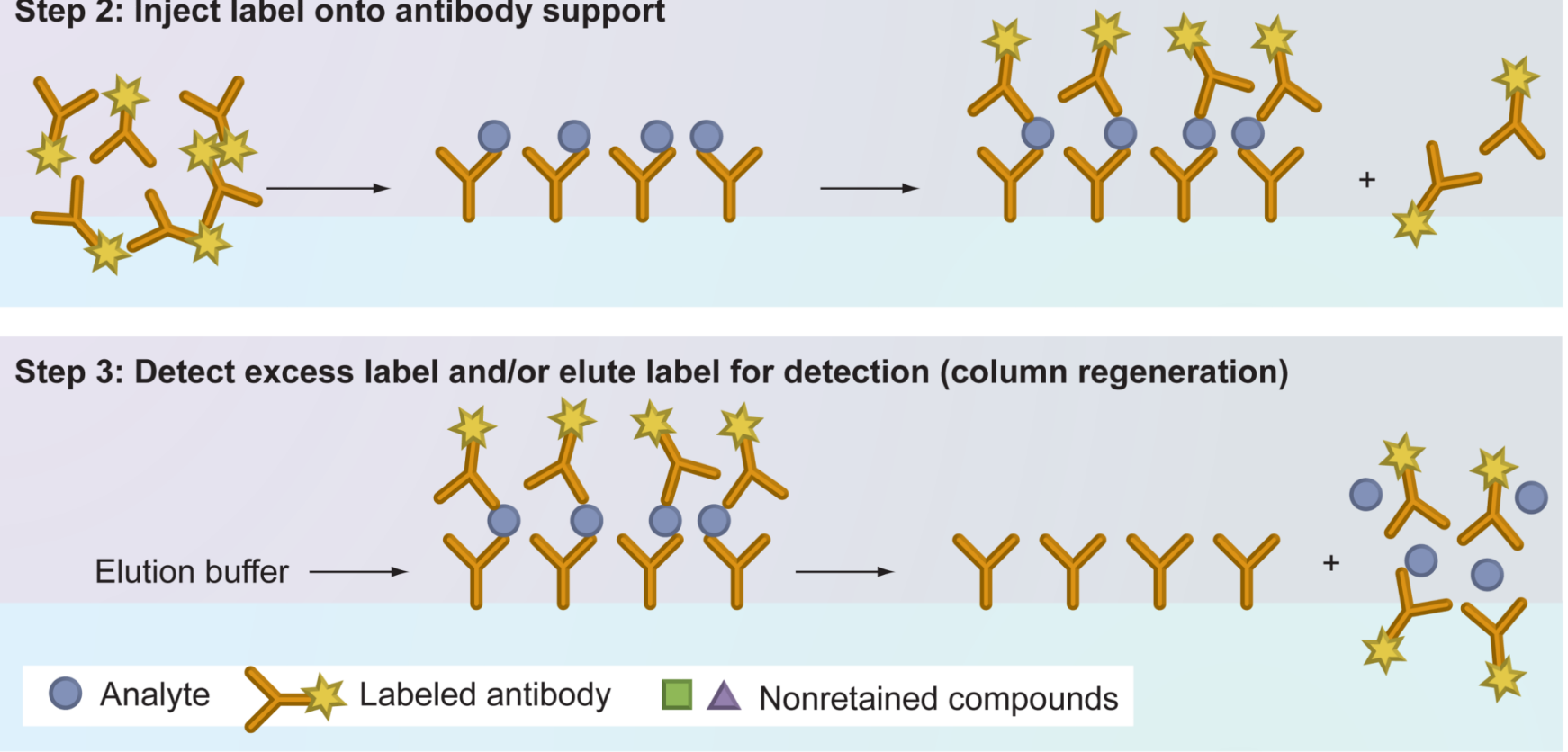

Figure 10. Sandwich immunoassay format

In this type of noncompetitive binding immunoassay, the sample is injected onto an immunoaffinity column and the analyte allowed to bind to the immobilized antibodies. A labeled antibody that is specific for the analyte is then injected onto the same column and also allowed to bind, creating a sandwich immune complex for the analyte. An elution buffer is applied to disrupt the antigen-antibody binding and regenerate the column. The amount of retained, labeled antibody that is eluted during this step is directly proportional to the amount of analyte that was present in the original sample. 


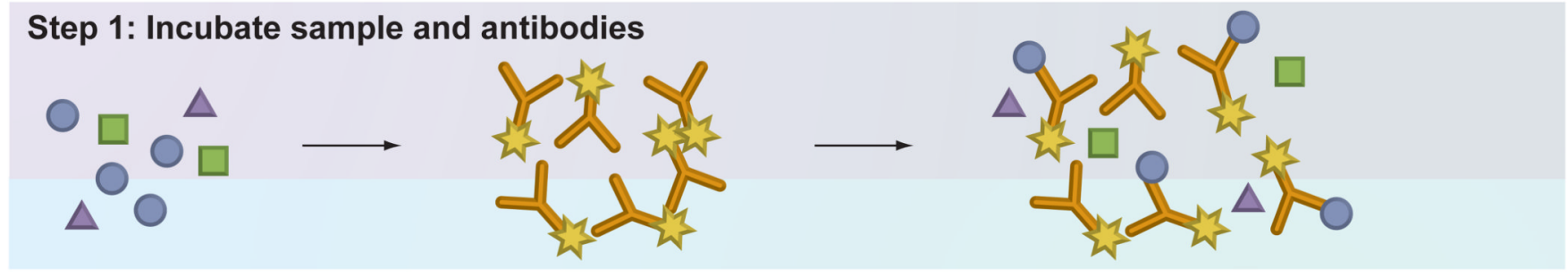

\section{Step 2: Inject mixture onto column and detect labeled antibodies}

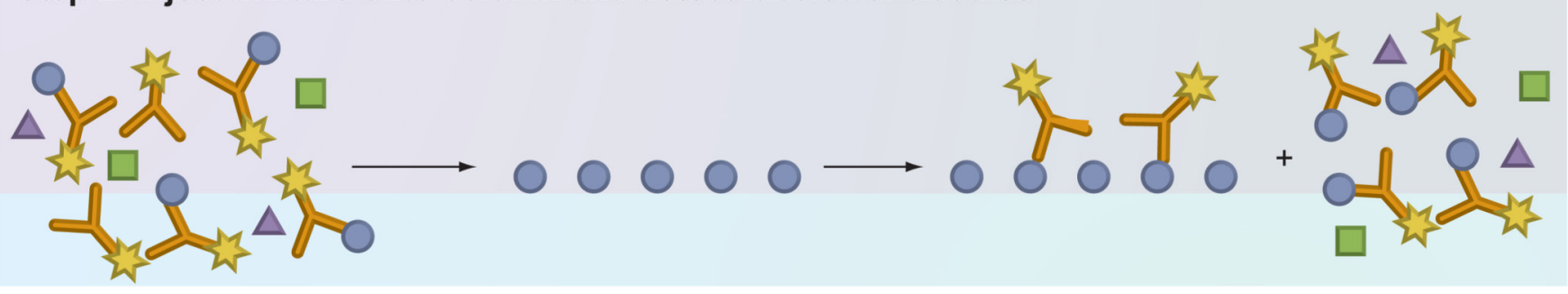

\section{Step 3: Regenerate column}

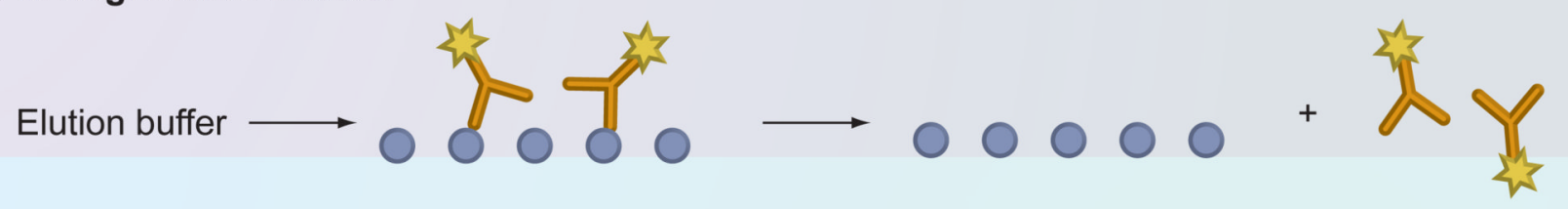

Analyte

$y=2^{2}$ Labeled antibody

$\triangle$ Nonretained compounds

Figure 11. One-site immunometric assay

In this noncompetitive immunoassay format, the analyte and labeled antibodies are mixed and incubated prior to injection onto an immobilized analyte column. The analyte column binds any excess antibodies and the analyte-bound antibodies are eluted in the nonretained fraction, providing a signal that is directly related to the analyte's original concentration. The column is later regenerated by eluting off the excess labeled antibodies. 


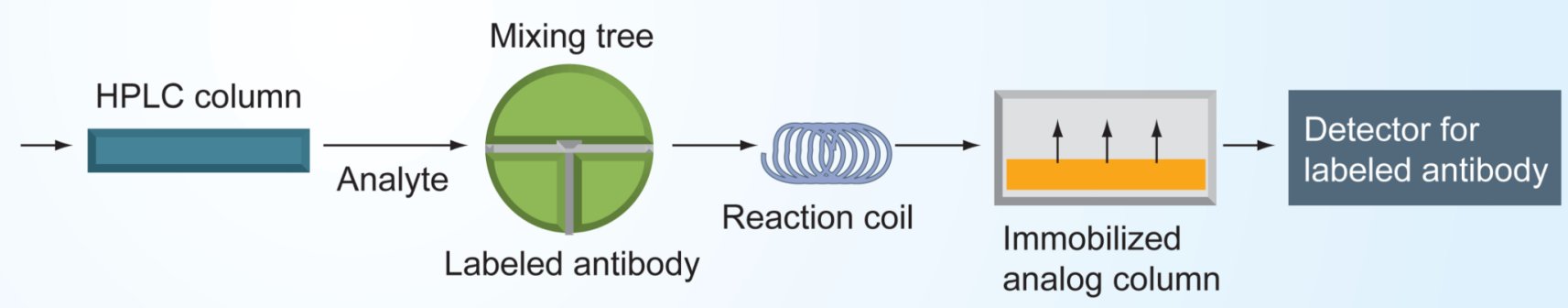

Figure 12. General scheme for postcolumn immunodetection

In this detection method, eluent from an HPLC column is directed into a reaction coil along with an excess of labeled antibodies that are able to bind the desired analyte. The excess antibodies bind to an immobilized analog column and the labeled analyte-antibody complexes are monitored as they elute from the analog column, providing a signal that is directly related to the original amount of eluting analyte. Reproduced with permission from [15]. () American Chemical Society (2001). 
Table 1

Commercially available supports that can be used for immunoaffinity chromatography.

\begin{tabular}{|ll|}
\hline Support type & Supplier \\
\hline Low- or medium-performance supports \\
\hline Affi-Gel & BioRad \\
\hline Affinica Agarose/Polymeric Supports & Schleicher and Schuell \\
\hline AvidGel & BioProbe \\
\hline Bio-Gel & BioRad \\
\hline Fractogel & EM Separations \\
\hline HEMA-AFC & Alltech \\
\hline Reacti-Gel & Pierce \\
\hline Sephacryl & Pharmacia \\
\hline Sepharose & Pharmacia \\
\hline Superose & Pharmacia \\
\hline Trisacryl & IBF \\
\hline TSK Gel Toyopearl & TosoHaas \\
\hline Ultragel & IBF \\
\hline High-performance supports & \\
\hline AvidGel CPG & BioProbe \\
\hline HiPAC & ChromatoChem \\
\hline Protein-Pak Affinity Packing & Waters \\
\hline Ultraafinity-EP & Bodman \\
\hline Emphaze & 3M Corp./Pierce \\
\hline POROS & ABI/PerSeptive Biosystems \\
\hline Data from [1]. & \\
\hline
\end{tabular}


Table 2

Examples of simultaneous injection immunoassays.

\begin{tabular}{|c|c|c|c|}
\hline Analyte & Detection method & Assay characteristics & Ref. \\
\hline \multicolumn{4}{|c|}{ Methods based on antibodies adsorbed on protein $A$ or protein $G$} \\
\hline Human transferrin & Fluorescence & Range: $<500 \mu \mathrm{g} / \mathrm{ml}$ & [103] \\
\hline Transferrin & Fluorescence & LOD: $25 \mu \mathrm{g} / \mathrm{ml}$ & [104] \\
\hline Adrenocorticotropic hormone & Fluorescence & Range: $0.2-10 \mathrm{mg} / 1$ & [105] \\
\hline Testosterone & Fluorescence & LOD: $0.5 \mu \mathrm{g} / \mathrm{ml}$ & [106] \\
\hline Theophylline & Fluorescence & LOD: $0.3 \mathrm{ng} / \mathrm{ml}$; range: $<500 \mu \mathrm{g} / \mathrm{l}$ & [107] \\
\hline Atrazine & Fluorescence & LOD: $2.1 \mu \mathrm{g} / \mathrm{l} ;$ range: $2.1-50 \mu \mathrm{g} / \mathrm{l}$ & [108] \\
\hline Cephalexin & Electrochemical & LOD: $1 \mu \mathrm{g} / 1$ & [109] \\
\hline $\operatorname{IgG}$ & Absorbance & LOD: $333 \mathrm{zmol}$ & [110] \\
\hline Theophylline & Electrochemical & LOD: $25 \mathrm{ng} / \mathrm{ml}$ & [111] \\
\hline Anti-BSA & Fluorescence & LOD: $0.2 \mathrm{nM}$; linear range: $0.4-0.8 \mathrm{nM}$ & [112] \\
\hline \multicolumn{4}{|c|}{ Methods based on covalently immobilized antibodies } \\
\hline HSA & Thermometric & LOD: $10^{-10} \mathrm{M}$ & [113] \\
\hline Theophylline & Fluorescence & LOD: $3 \mu \mathrm{g} / 1$; range: $3-75 \mu \mathrm{g} / \mathrm{l}$ & [102] \\
\hline Pullulanase, IgG, antithrombin & Fluorescence & Range: $\mu \mathrm{g} / \mathrm{ml}$ & [114] \\
\hline $\operatorname{IgG}$ & Fluorescence & LOD: $155 \mathrm{ng} / \mathrm{ml}$ & [115] \\
\hline $\operatorname{IgG}$ & Fluorescence & LOD: $4 \times 10^{-9} \mathrm{M}$ & [116] \\
\hline Gentamicin & Fluorescence & LOD: $200 \mathrm{ng} / \mathrm{ml}$; working range: $250-5000 \mathrm{ng} / \mathrm{ml}$ & [117] \\
\hline $\operatorname{IgG}$ & Fluorescence & Linear range: $1-5 \mu \mathrm{g} / \mathrm{ml}$ & [118] \\
\hline Insulin & Thermometric & LOD: $0.025 \mu \mathrm{g} / \mathrm{ml}$; working range: $0.05-2 \mu \mathrm{g} / \mathrm{ml}$ & [119] \\
\hline Carbaryl & Fluorescence & LOD: $20 \mathrm{ng} / \mathrm{l}$ & [120] \\
\hline Atrazine & Fluorescence & LOD: 75 ng/l & [121] \\
\hline Isoproturon & Absorbance & LOD: $0.09 \mu \mathrm{g} / 1$ & [122] \\
\hline Gentamicin & Thermometric & Range: $10-400 \mu \mathrm{g} / 1$ & [123] \\
\hline $\operatorname{IgG}$ & Electrochemical & & [124] \\
\hline Digoxin & Chemiluminescence & LOD: $0.2 \mathrm{ng} / \mathrm{ml}$ & [125] \\
\hline $\operatorname{IgG}$ & Chemiluminescence & LOD: 7 fmol & [126] \\
\hline Theophylline & Fluorescence & & [127] \\
\hline Theophylline & Fluorescence & Range: $0.025-0.4 \mathrm{mg} / \mathrm{l}$ & [128] \\
\hline Theophylline, caffeine & Fluorescence & Range: $3 \times 10^{-5}-3 \times 10^{-8} \mathrm{M}$ & [188] \\
\hline Antitheophylline & Fluorescence & Range: $4 \times 10^{-7}-6 \times 10^{-9} \mathrm{M}$ & [188] \\
\hline Methotrexate & Radioactivity & Range: $1-100 \mu \mathrm{g} / 1$ & [129] \\
\hline Thyroxine & Electrochemical & LOD: $25 \mu \mathrm{g} / 1 ;$ linear range: $25-50 \mu \mathrm{g} / 1$ & [130] \\
\hline Cortisol & Fluorescence & Range: $1-60 \mu \mathrm{g} / \mathrm{dl}$ & [131] \\
\hline
\end{tabular}


Table 3

Examples of sequential injection immunoassays.

\begin{tabular}{|lllc|}
\hline Analyte & Detection method & Assay characteristics & Ref. \\
\hline Imazethapyr & Fluorescence & LOD: $500 \mathrm{ppb}$ & {$[134]$} \\
\hline Imazethapyr & Fluorescence & LOD: $0.5 \mathrm{ppb}$ & {$[134]$} \\
\hline IgG & Thermometric & Range: $10-400 \mu \mathrm{g} / \mathrm{ml}$ & {$[135]$} \\
\hline IgG & Thermometric & LOD: $33 \mathrm{pmol}$ & {$[136]$} \\
\hline Digoxin & Electrochemical & LOD: $10 \mathrm{pg} / \mathrm{ml}$; range: $10-1000 \mathrm{pg} / \mathrm{ml}$ & {$[137]$} \\
\hline Atrazine & Fluorescence & Range: $0.02-0.3 \mu \mathrm{g} / \mathrm{l}$ & {$[138]$} \\
\hline Atrazine & Fluorescence & Range: $0.03-0.5 \mu \mathrm{g} / 1$ & {$[139]$} \\
\hline HSA & Electrochemical & & {$[140]$} \\
\hline$\alpha$-amylase & Absorbance & & {$[141$} \\
\hline Anti-IgG & Chemiluminescence & LOD: $1 \mathrm{fmol}$ & {$[142]$} \\
\hline Imazethapyr & Fluorescence & LOD: $0.1 \mathrm{ppb}$ & {$[143]$} \\
\hline Imazethapyr & Fluorescence & Range: $0.1-100 \mathrm{ng} / \mathrm{ml}$ & {$[144]$} \\
\hline
\end{tabular}


Table 4

Examples of displacement immunoassays.

\begin{tabular}{|lllc|}
\hline Analyte & Detection method & Assay characteristics & Ref. \\
\hline $\begin{array}{l}\text { Cocaine, } \\
\text { benzoylecgonine }\end{array}$ & Fluorescence & & {$[149]$} \\
\hline TNT, DNT & Fluorescence & LOD: $2.5 \mathrm{ng} / \mathrm{ml}$; range: 20-1200 ng/ml & {$[148]$} \\
\hline $\begin{array}{l}\text { Cocaine, } \\
\text { benzoylecgonine }\end{array}$ & Fluorescence & & {$[150]$} \\
\hline 2,4-dinitrophenol & Radioactivity & $\begin{array}{l}\text { LOD: } 140 \mathrm{nM} \text {; linear range: } \\
\text { 570-4600 nM }\end{array}$ & {$[147]$} \\
\hline 2,4-dinitrophenol & Fluorescence & Linear range: 290-2300 nM & {$[147]$} \\
\hline Cortisol & Fluorescence & Dynamic range: $12.5-1250 ~ p m o l$ & {$[151]$} \\
\hline $\begin{array}{l}\text { Polychlorinated } \\
\text { biphenyls }\end{array}$ & Fluorescence & LOD: 4 ppm; linear range: 4-20 $\mu \mathrm{gg} / \mathrm{ml}$ & {$[152]$} \\
\hline Transferrin, HSA & Absorbance & & {$[153]$} \\
\hline
\end{tabular}


Table 5

Examples of sandwich immunoassays.

\begin{tabular}{|lllr|}
\hline Analyte & Detection method & Assay characteristics & Ref. \\
\hline $\begin{array}{l}\text { Thyroid-stimulating } \\
\text { hormone }\end{array}$ & Absorbance & Range: $0-0.29 \mathrm{nM}$ & {$[154]$} \\
\hline hCG & Fluorescence & Range: $0-66.6 \mathrm{ng} / \mathrm{ml}$ & {$[154]$} \\
\hline HSA & Fluorescence & LOD: $0.001 \mathrm{mg} / \mathrm{ml}$ & {$[59]$} \\
\hline PTH, interleukin-5 & Fluorescence & LOD: $10 \mathrm{nM}$; linear range: $<250 \mu \mathrm{M}$ & {$[155]$} \\
\hline IgG & Absorbance & LOD: $3 \mathrm{fmol}$; range: $3.33-130 \mathrm{fmol}$ & {$[110]$} \\
\hline IgG & Fluorescence & Linear range: $0.5-50 \mathrm{pmol} / 1$ & {$[156]$} \\
\hline HSA & Electrochemical & Range: $1-10 \mathrm{mg} / \mathrm{ml}$ & {$[157]$} \\
\hline Anti-IgG & Electrochemical & Range: $3-225 \mathrm{fmol}$ & {$[158]$} \\
\hline IgG & Electrochemical & Range: $5-400 \mathrm{ng} / \mathrm{ml}$ & {$[159]$} \\
\hline IgG & Chemiluminescence & Range: $0.2-20 \mathrm{fmol}$ & {$[160]$} \\
\hline $\begin{array}{l}\text { Parathyroid } \\
\text { hormone }\end{array}$ & Chemiluminescence & $\begin{array}{l}\text { LOD: } 0.24 \mathrm{pM}(16 \mathrm{amol}) ; \\
\text { linear range: } 0.24-67 \mathrm{pM}\end{array}$ & {$[161]$} \\
\hline
\end{tabular}


Table 6

Examples of one-site immunometric assays.

\begin{tabular}{|c|c|c|c|}
\hline Analyte & Detection method & Assay characteristics & Ref. \\
\hline $\begin{array}{l}\text { Granulocyte colony- } \\
\text { stimulating factor }\end{array}$ & Fluorescence & LOD: $1.5 \mathrm{ng} / 120 \mu 1$ & [163] \\
\hline Digoxin and metabolites & Fluorescence & LOD: $2 \times 10^{-10} \mathrm{M}$ & [164] \\
\hline Digoxin and metabolites & Fluorescence & $\begin{array}{l}\text { LOD: } 160 \mathrm{pg} / \mathrm{ml} \text {; linear range: } \\
0.2-2 \mathrm{nmol} / \mathrm{l}\end{array}$ & [165] \\
\hline Digoxin & Fluorescence & LOD: $200 \mathrm{fmol}$ & [166] \\
\hline Digoxigenin & Fluorescence & $\begin{array}{l}\text { LOD: } 50 \mathrm{fmol} \text {; linear range } \\
50-1000 \mathrm{fmol}\end{array}$ & [167] \\
\hline Digoxin & Fluorescence & LOD: $0.025 \mathrm{nM}$ & [167] \\
\hline Digoxigenin & Fluorescence & LOD: $0.01 \mathrm{nM}$ & [167] \\
\hline Interleukin-10 & Fluorescence & LOD: $40 \mathrm{fmol}$ & [168] \\
\hline Digoxin & Absorbance & LOD: $0.2 \mu \mathrm{g} / 1$ & [169] \\
\hline 2,4-D & Electrochemical & LOD: $0.25 \mu \mathrm{g} / 1$ & [170] \\
\hline Digoxigenin & Electrochemical & $\begin{array}{l}\text { LOD: } 0.5 \mathrm{amol} ; \text { linear range: } \\
0.38-7.7 \mathrm{fmol}\end{array}$ & [171] \\
\hline$\alpha$-(difuoromethyl)-ornithine & Fluorescence & $\begin{array}{l}\text { LOD: } 200 \text { amol; linear range: } \\
5 \times 10^{-11}-2.5 \times 10^{-9} \mathrm{M}\end{array}$ & [172] \\
\hline Fatty acid-binding protein & Absorbance & Range: $1-12 \mu \mathrm{g} / 1$ and $12-2000 \mu \mathrm{g} / 1$ & [173] \\
\hline Thyroxine & Chemiluminescence & LOD: $10^{-11} \mathrm{M}$ & [174] \\
\hline $\begin{array}{l}\text { 4-amino-L- and } \\
\text { D-phenylalanine }\end{array}$ & Chemiluminescence & LOD: $1.76 \mathrm{pmol} / \mathrm{ml}$ & [175] \\
\hline 17-estradiol & Fluorescence & & [176] \\
\hline$\alpha$-fetoprotein & Fluorescence & $\begin{array}{l}\text { LOD: } 0.1 \mathrm{ng} / \mathrm{ml} \text {; linear range: } \\
0.5-60 \mathrm{ng} / \mathrm{ml}\end{array}$ & [177] \\
\hline Terbutryn & Grating coupler & $\begin{array}{l}\text { LOD: } 15 \mu \mathrm{g} / 1 \text {; linear range: } \\
20-200 \mu \mathrm{g} / 1\end{array}$ & [178] \\
\hline
\end{tabular}

